\title{
Impact of relative sea level and rapid climate changes on the architecture and lithofacies of the Holocene Rhone subaqueous delta (Western Mediterranean Sea)
}

\author{
Anne-Sophie Fanget ${ }^{a, *}$, Serge Berné ${ }^{a, b}$, Gwénaël Jouet ${ }^{b}$, Maria-Angela Bassetti ${ }^{a}$, Bernard \\ Dennielou ${ }^{b}$, Grégoire M. Maillet ${ }^{c}$, Mathieu Tondut ${ }^{\mathrm{a}}$
}

\begin{abstract}
a Université de Perpignan Via Domitia, Centre de Formation et de Recherche sur les Environnements Méditerranéens (CEFREM), UMR 5110-CNRS, F-66860, Perpignan, France

${ }^{b}$ IFREMER, Géosciences Marines, Centre de Brest, BP70, 29280 Plouzané, France

c Université d'Angers, UMR CNRS 6112 LPG-BIAF Bio-Indicateurs Actuels et Fossiles, 2 Boulevard Lavoisier, 49045 Angers Cedex 01, France
\end{abstract}

\author{
*: Corresponding author: Anne-Sophie Fanget, tel.: + 33468661745 ; fax: + 33468661747 ; \\ email address : anne-sophie.fanget@univ-perp.fr
}

\begin{abstract}
:
The modern Rhone delta in the Gulf of Lions (NW Mediterranean) is a typical wave-dominated delta that developed after the stabilization of relative sea level following the last deglacial sea-level rise. Similar to most other deltas worldwide, it displays several stacked parasequences and lobes that reflect the complex interaction between accommodation, sediment supply and autogenic processes on the architecture of a wave-dominated delta. The interpretation of a large set of newly acquired very high-resolution seismic and sedimentological data, well constrained by ${ }^{14} \mathrm{C}$ dates, provides a refined three-dimensional image of the detailed architecture (seismic bounding surfaces, sedimentary facies) of the Rhone subaqueous delta, and allows us to propose a scenario for delta evolution during the last deglaciation and Holocene. The subaqueous delta consists of "parasequence-like" depositional wedges, a few meters to 20-30 $\mathrm{m}$ in thickness. These wedges first back-stepped inland toward the NW in response to combined global sea-level rise and overall westward oceanic circulation, at a time when sediment supply could not keep pace with rapid absolute (eustatic) sea-level rise. At the the Younger Dryas-Preboreal transition, more rapid sea-level rise led to the formation of a major flooding surface (equivalent to a wave ravinement surface). After stabilization of global sea level in the midHolocene, accommodation became the leading factor controlling delta architecture. An eastward shift of depocenters occurred, probably favoured by higher subsidence rate within the thick Messinian Rhone valley fill. The transition between transgressive (backstepping geometry) and regressive (prograding geometry) (para)sequences resulted in creation of a Maximum Flooding Surface (MFS) that differs from a "classical" MFS described in the literature. It consists of a coarse-grained interval incorporating reworked shoreface material within a silty clay matrix. This distinct lithofacies results from condensation/erosion, which appears as an important process even within supply-dominated deltaic systems, due to avulsion of distributaries. The age of the MFS varies along-strike between ca. 7.8-5.6 kyr cal. BP in relation to the position of depocenters and climatically-controlled sediment supply. The last rapid climate change of the Holocene, the Little Ice Age (1250-1850 AD), had a distinct stratigraphic influence on the architecture and lithofacies of the Rhone subaqueous delta through the progradation of two deltaic lobes. In response to changes in sediment supply linked to
\end{abstract}


rapid climate changes (and to anthropic factors), the Rhone delta evolved from wave-dominated to fluvial dominated, and then wave dominated again.

Keywords : Delta ; Holocene ; Maximum Flooding Surface ; sea level ; tempestites ; Western Mediterranean

\section{Introduction}

Modern deltas are the focus of increased interest since many are densely populated and at risk of flooding in relation with global sea-level rise and decrease of sediment delivery to the sea (Syvitski et al., 2009). In recent years, they have been the object of detailed investigations in the framework of international programs such as "Eurodelta" (Trincardi et al., 2004) or "Asian deltas" (Saito, 2005). Deltas are also important components of the sedimentary record since they correspond to subsiding areas where large amount of sediments are delivered at river mouths. Their preserved architecture is particularly sensitive to interactions between the rates of changes of sediment flux and accommodation. As a result, conceptual developments in sequence stratigraphy were largely fuelled by the analysis of deposits interpreted as ancient deltas (i.e., parasequences, van Wagoner et al., 1990). For this purpose, modern deltas offer a possibility to explore and validate some of these concepts of sequence stratigraphy in a 
framework where some controlling parameters (eustasy, hydrodynamic processes, sediment fluxes) are better known than for the rock record.

The marine components of deltas include delta fronts and prodeltas (Bhattacharya, 2006). The delta front corresponds to sandy deposits formed at the outlet of rivers and reworked by waves, distributary channel migration and gravity processes (in wave-dominated deltas, delta fronts correspond to the foreshore and upper shoreface of siliciclastic shorelines). At greater depths (ca. 10 to $50 \mathrm{~m}$ ), delta front sands pass to muddy sediments of the prodelta where sedimentation is controlled by settling of fine-grained particles from surficial plumes or nearbottom fluid mud transported by gravity processes. In cases where wave and current energy is high, some of the mud delivered by the rivers does not remain in the prodelta, but is transported further offshore where it forms clinoformed sediment bodies on the mid-shelf. This process was first described on the Amazon shelf (Nittrouer et al., 1986), and is now recognized worldwide (Pratson et al., 2007). Such sediment bodies are named subaqueous deltas by some authors (i.e., Cattaneo et al., 2003). In this paper we use this term for describing the presently-subaqueous sediment bulge situated within the modern delta plain (Berné et al., 2007; Riboulot et al., 2012). The distribution of sedimentary facies within modern deltas, and the history of their progradation in relation with changes in fluvial discharge and relative sea-level rise changes, have been mainly studied through core data from various delta plains, e.g., the Rhine-Meuse (Berendsen and Stouthamer, 2000), the Changjiang and Huang Ho (Saito et al., 2001), the Red River (Tanabe et al., 2003), the Mekong (Ta et al., 2002), and the Rhone (Amorosi et al., 2013). In contrast, studies including the subaqueous components of these deltas are rather scarce (e.g., Somoza et al., 1998; Correggiari et al., 2005a; 2005b).

On the basis of a new seismic and core data set, well constrained through $47{ }^{14} \mathrm{C}$ AMS dates, we present here a scenario for the evolution of the Rhone subaqueous delta during the 
Holocene. Our study includes the remains of the delta front/prodelta components of the early Rhone delta (Transgressive Systems Tract), left across the mid-shelf during rapid backstepping of the delta during the deglacial and early Holocene, and the various prodeltaic lobes that compose part of the middle-late Holocene Highstand Systems Tract. This scenario incorporates the possible impact of rapid climate changes during the Holocene, and shows how changes in water and sediment discharges related to rapid climate events influenced lobe avulsion and prodeltaic sedimentary facies and architecture.

\section{Regional setting}

\subsection{General geological framework}

The Gulf of Lions (Fig. 1) is a siliciclastic passive and prograding continental margin formed during the Oligo-Aquitanian rifting and Burdigalian crustal opening between continental Europe and the Corsica-Sardinia microplate (Gueguen, 1995; Speranza et al., 2002). Located in the north-western sector of the Mediterranean Sea, the Gulf of Lions is bounded to the west and to the east by Pyrenean and Alpine orogenic belts, respectively. It comprises a crescentshaped continental shelf with a maximum width of $70 \mathrm{~km}$ in the central part. Most (80\%) of shelf sediments are supplied by the Rhone River (Aloïsi et al., 1977). They originate from a broad watershed $\left(98000 \mathrm{~km}^{2}\right)$ including western and southern Alps, Massif Central and Jura. Plio-Quaternary shelf sediments overlay the Messinian erosional uncomformity (Hsü et al., 1973). They are characterized by prograding geometries (Lofi et al., 2003) and a significant subsidence rate (250 m/Myr at the shelf edge; Rabineau et al., 2005). The Upper Quaternary sequences are made of five stacked prograding wedges (named S1 to S5; Rabineau et al., 2005), which correspond to Pleistocene forced regressions that formed during 100 kyr glacio- 
eustatic cycles (Aloïsi, 1986; Rabineau et al., 1998; Tesson et al., 2000; Rabineau et al., 2005; Jouet et al., 2006; Bassetti et al., 2008). They represent the most significant element constituting the outer shelf sequences. They are topped by a regional unconformity (D200 in Labaune et al., 2005, also labelled D70 in the median-outer shelf by Rabineau et al., 2005 and Jouet et al., 2006) that represents the Last Glacial Maximum (LGM, around $21 \mathrm{kyr}$ cal. BP; Mix et al., 2001) sequence boundary. At the seismic resolution scale, the sequence boundary of the LGM (D200) is generally merged with the post-LGM ravinement surface. There is evidence that, during the LGM, several distributaries of the Rhone were directly connected to the Marti and Petit Rhone (and possibly Grand Rhone and Herault) canyons (Berné et al., 2007) (Fig. 1). Following the LGM, the deglacial (ca. 21-11.7 kyr cal. BP) and Holocene (11.7-0 kyr cal. BP; Walker et al., 2009) deposits, well developed on the middle and inner shelf, overlie Pleistocene regressive deposits. The present-day Rhone delta occupies a deeplyincised Messinian valley, filled with up to $2 \mathrm{~km}$ of Plio-Quaternary sediments (Lofi et al., 2003).

\subsection{Stratigraphy of the Rhone delta deglacial and Holocene deposits}

\subsubsection{Transgressive (deglacial and early Holocene) deltaic sedimentation}

The modern Rhone delta is a moderately wave-dominated delta in the "Galloway" classification (Galloway, 1975, revised by Bhattacharya and Walker, 1992). Compared to many other deltas in the world, it is a symmetric delta (Bhattacharya and Giosan, 2003), where beach ridges developed on both sides of former distributaries. Presently, two distributaries exist, the "Petit Rhône" Channel and the "Grand Rhône" Channel, situated to the west and to the east of the delta plain, respectively (Fig. 1). The subaqueous part of the 
delta was mainly described from seismic investigations (Aloïsi et al., 1975; Marsset and Bellec, 2002; Gensous and Tesson, 2003; Labaune et al., 2005; Berné et al., 2007; Labaune et al., 2008). Only a few long cores were retrieved from the prodelta (Berné et al., 2007). During post-LGM sea-level rise, the Rhone outlet(s) migrated landward, leaving a series of backstepping parasequences from the shelf edge to the modern inner shelf (the "shoal retreat Massif" of Swift et al. (1978)). Along the Rhone retreat path, chaotic seismic facies (unit U200 in Labaune et al., 2005) were interpreted as transgressive fluvial deposits (Aloïsi et al., 1975). These deposits have never been sampled, but their age can be estimated between ca. 20-15 kyr cal. BP, based on their position above the LGM sequence boundary and below Bølling-Allerød prodeltaic muds (Berné et al., 2007). Between ca. 15-7 kyr cal. BP, the main depocenters migrated landward (in response to global sea-level rise) and westward (probably due to the wind-driven circulation), forming the Early Rhone Deltaic Complex (ERDC corresponding to U400, Fig. 1) described by Berné et al. (2007).

\subsection{2. "Highstand" (middle and late Holocene) deltaic sedimentation}

Following the rapid decrease of global Holocene sea-level rise around $6 \mathrm{kyr}$ cal. BP (Stanford et al., 2011), the Rhone deltaic system progressively shifted eastward. So far, the record of this evolution is mainly documented by studies carried out in the deltaic plain (Kruit, 1955; Oomkens, 1970; L'Homer et al., 1981; Arnaud-Fassetta, 1998; Vella and Provansal, 2000; Provansal et al., 2003; Boyer et al., 2005; Vella et al., 2005; 2008), including some long boreholes. In the offshore domain, seismic units were identified, and tentatively correlated to onshore studies by Labaune et al. (2005), but the lack of chrono-stratigraphic constraints prevented precise correlations. Regarding onshore studies, several major deltaic lobes are 
identified; they formed in response to the successive displacement of the Rhone distributaries under natural and/or anthropic influence (Fig. 2).

The Saint Ferréol lobe is the oldest and main paleo-deltaic lobe. The beginning of the Saint Ferréol progradation is attested $7 \mathrm{kyr}$ cal. BP (L'Homer et al., 1981). Maximum advance is estimated between 2.8-2 kyr cal. BP (Vella et al., 2008). The pulsed progradation of this lobe is related to several phases of high sediment supply identified on the deltaic plain (Bruneton et al., 2001; Arnaud-Fassetta, 2002; Provansal et al., 2003). The activity of the "Rhône de Saint Ferréol" Channel started declining around the Roman Period, and the progressive filling of this channel took place between the II and VI centuries AD (Arnaud-Fassetta et al., 2000; Provansal et al., 2003).

The age of the Ulmet lobe, located eastward, is constrained by only a few ${ }^{14} \mathrm{C}$ dates. The "Rhône d'Ulmet" Channel appears to be synchronous with the "Rhône de Saint Ferréol" Channel, with a period of activity estimated between $6.5 \mathrm{kyr}$ cal. BP and the Medieval Period (Vella et al., 2005). The "Rhône d'Ulmet" Channel was artificially closed in 1440 AD in favour of the "Rhône de Grand Passon" Channel (Rossiaud, 1994, in Arnaud-Fassetta, 1998).

The Peccais lobe, located farther to the west, appeared posterior to the activity of the Saint Ferréol and Ulmet lobes (Rey et al., 2005; Vella et al., 2005). The "Rhône de Peccais" Channel is thought to have been active until $1552 \mathrm{AD}$, before shifting artificially eastward to the present-day position of the "Petit Rhône" Channel (Kruit, 1955). It was proposed that the Bras de Fer lobe formed during the Little Ice Age, between 1587-1711 AD (ArnaudFassetta, 1998), a period of high flood frequency and magnitude (Pichard, 1995), but only a few ${ }^{14} \mathrm{C}$ dates exist onshore for this time interval, most of the information relying on historical archives (Arnaud-Fassetta and Provansal, 1999). The "Rhône du Bras de Fer" Channel is considered synchronous with the "Rhône du Grand Passon" Channel until 1650 AD (Arnaud- 
Fassetta, 1998). After several intense floods between 1709-1711 AD, the "Rhône de Bras de Fer" Channel naturally shifted to the east, at the position of the present-day "Grand Rhône" Channel. Between 1711-1852 AD, the seaward termination of the "Grand Rhône" Channel was divided into three mouths called (1) the Piémanson mouth to the west, (2) the Roustan mouth at the centre, and (3) the Pégoulier mouth to the east. In 1855 AD, the Piémanson and Roustan mouths were closed by dykes in order to facilitate sediment evacuation and to improve the fluvial navigation. Consequently, the flow was constrained into a single distributary, the "Pégoulier" Channel. In 1892 AD, the Roustan mouth was re-opened for navigation and the "Pégoulier" Channel was progressively filled in. Since 1892 AD, the flow is artificially confined into the "Roustan" Channel, at the origin of the modern Roustan lobe.

It must be emphasized that most of the ages assigned to the various deltaic lobes are based on ${ }^{14} \mathrm{C}$ dating of shells from beach ridges (L'Homer et al., 1981; Vella et al., 2008). Such deposits of them incorporate reworked material. Only the recent borehole of Amorosi et al. (2013) provides four ${ }^{14} \mathrm{C}$ dates from the prodeltaic muds of the St Ferréol lobe situated underneath the modern delta plain.

\subsection{Hydrodynamic conditions}

The shelf of the Gulf of Lions is wave-dominated, with moderate energy and weak tidal currents (tidal range less than $0.3 \mathrm{~m}$ ). Water circulation and sediment transport are controlled by wind-driven circulation and/or wave regime. Winds are dominantly from the NNW (continental cold and dry winds Mistral and Tramontane). These winds have little impact on sediment transport due to a short fetch (30\% of the total regime; significant wave height $\mathrm{H}_{\mathrm{s}}<2 \mathrm{~m}$, and peak period $\mathrm{T}_{\mathrm{p}}<6 \mathrm{~s}$; Sabatier, 2001) on the inner shelf. Episodic and intense 
winds from the ESE (Marin) sector have the most significant impact on sediment transport in the study area. They are associated with long fetch and generate SSE (16\% of the total regime) and SE (11\% of the total regime) storm waves, with a significant wave height in excess of $7 \mathrm{~m}$, and a peak period up to $12 \mathrm{~s}$ (Guillén et al., 2006; Palanques et al., 2006). The storms generated by these winds induce intense wind-driven circulation, able to transport sediment in an alongshore direction all over the inner shelf (Dufois et al., 2008). These winds also induce a rise in sea level at the shore, and an intense cyclonic circulation on the shelf (Ulses et al., 2008). They are often associated to low pressure and rainfall over the catchment area of the Rhone, generating major river floods. The combination of such flooding events together with ESE storm waves, named "wet storms" (Guillén et al., 2006), has major implication on depositional processes in the deltaic/prodeltaic area. At the coast, the wave regime leads to the lateral redistribution of sands and causes an alongshore drift cells pattern (Sabatier and Suanez, 2003; Sabatier et al., 2006) (Fig. 2). Thus, the Rhone delta shoreline displays accretion (Espiguette, Beauduc, and Gracieuse spits), which is also partly fed by erosion of the relict prodeltaic lobes (St Ferréol, Bras de Fer, and Pégoulier) reworked by waves.

\section{Data and Methodology}

This study is based on a large seismic and core data set collected during the RHOSOS cruise (September 2008) on board $R / V$ "Le Surôtt". We also utilised seismic data collected during previous cruises, as synthesized in Labaune et al. (2005). Seismic data were acquired using a mud penetrator (Chirp) source. The vertical resolution of the hull-mounted Chirp system of $R / V$ "Le Suroît" (2 000 to $5200 \mathrm{~Hz}$ ) is in the range of $30-50 \mathrm{~cm}$ and a long impulse (from $20 \mathrm{~ms}$ to $50 \mathrm{~ms}$ ) was linearly modulated in time and frequency (Schock et al., 1989). A simple 
processing flow was applied on the FM signal to improve the signal/ratio noise. This processing includes cross-correlation between raw data and emitted Chirp sweep, frequency band filters, and amplitude corrections and envelope. Interpretation was carried out on a Kingdom Suite ${ }^{\mathrm{TM}}$ work station in order to map seismic surfaces and units, and to correlate them with cores using velocity analysis where available. Seismic interpretation was based on the principles of seismic stratigraphy (Mitchum et al., 1977). However, Chirp seismic data are more difficult to interpret as "conventional" seismic data and, furthermore, stratal terminations do not have always necessarily the same significance. Seismic bounding surfaces, in our case, are either discontinuities in the sense of Mitchum et al. (1977) or boundaries between distinct seismic facies (for instance, between transparent and stratified facies).

Eleven cores were retrieved from various deltaic lobes at water depth ranging from $-19.8 \mathrm{~m}$ to $-86 \mathrm{~m}$. All cores were split, photographed and visually described to identify sedimentological facies. The correlations with the seismic profiles were carried out using P-wave velocity measured with a GEOTEK ${ }^{\mathrm{TM}}$ Multi-Sensor Core Logger (MSCL) or using an average acoustic velocity of $1600 \mathrm{~m} \mathrm{~s}^{-1}$.

Well-preserved shells or benthic foraminifera were collected for ${ }^{14} \mathrm{C}$ dating. Radiometric dates were obtained with accelerator mass spectrometer (AMS) ${ }^{14} \mathrm{C}$ at Laboratoire de Mesure $14 \mathrm{C}$ (LMC14) at Commissariat à l'Energie Atomique (CEA, Saclay) through the ARTEMIS Programme, and at Poznan Radiocarbon Laboratory (PRL). The ages reported herein are $\delta^{13} \mathrm{C}$-normalised conventional ${ }^{14} \mathrm{C}$ years, corrected for an assumed air-sea reservoir effect of 400 years. Calendar ages were calculated using the Calib 6.0.1 version and the Marine 09 calibration curve (Reimer et al., 2009). The ages are given with 1 sigma standard error (in order to be comparable with previous dates published from the same area). We experienced difficulties in dating the most proximal cores, due to the low quantity of biogenic material. As 
a result, the quantity of dated material was sometimes lower than $1 \mathrm{mg} \mathrm{C}$ (as recommended by ARTEMIS), which might explain some age inversions (see Fig. 7; Table 1).

\section{Results and interpretations}

\subsection{Seismic architecture of the Deglacial and Holocene deposits}

Within the Deglacial and Holocene deposits, seven seismic discontinuities (D200 to D620) and seven seismic units (U200 to U620) were utilized on the basis of the nomenclature defined by Labaune et al. (2005). Using the "Rhosos" new seismic data set, we implemented the description of Deglacial seismic units and surfaces, previously described by several authors (Marsset and Bellec, 2002; Gensous and Tesson, 2003; Labaune et al., 2005; Berné et al., 2007; Labaune et al., 2008), then described more precisely the Holocene units that represent the focus of this paper.

The basal discontinuity of deglacial deposits (labelled D200 in this study) has been previously described as the sequence boundary corresponding to the LGM major sea-level fall (Labaune et al., 2005; see Section 2.1). It is a surface with clear erosional features that can be followed at the regional scale. On seismic images, it is marked by very high amplitude reflections and toplap terminations (Figs. 3-5); it displays an undulated morphology and forms an overall planar surface very gently dipping seaward.

Above D200, seismic unit $\mathbf{U 2 0 0}$ displays chaotic or very discontinuous internal reflections (Figs. 3-5). This unit rests on Pleistocene deposits, and pinches out eastward. An isopach map of this unit (Labaune et al., 2005) suggests that it corresponds to the retreat path of the Rhone River mouth during sea-level rise and corresponds to the "lower parasequence" of the deglacial Transgressive Systems Tract (TST). 
In the study area, the upper boundary of U200 is an erosional and undulated surface called

D400. It is a downlap surface observed through the whole seismic database, except in front of the modern Roustan deltaic lobe (Figs. 4, 5). D400 corresponds to the transition between transgressive (below D400) and regressive (above D400) deposits formed during the Younger Dryas stillstand (or decelerating relative sea-level rise) (Berné et al., 2007).

Seismic U400 displays important lateral variability. In the westernmost study area, which corresponds to the position of the Early Rhone Deltaic Complex, U400 is characterized by seaward dipping clinoforms (angle of dip between 0.5 and $1^{\circ}$ ). Eastward, U400 evolves into more chaotic or very discontinuous sub-horizontal internal reflections gently dipping seaward and downlapping on D400 (Figs. 3-5). From a sequence stratigraphic point of view, U400 is interpreted as a transgressive parasequence corresponding to the paleo-deltaic Rhone complex (the ERDC) formed during the Younger Dryas/Preboreal.

The upper boundary of seismic U400, called D450, is an erosional surface, forming incisions, up to $20 \mathrm{~ms}$ in depth, in the eastern part of the ERDC (Figs. 4, 5). We interpret the incisions as the result of fluvial (or tidal, at the position of tidal inlets) scouring.

Seismic $\mathbf{U 4 5 0}$ corresponds to a major cut-and-fill structure, centred in front of the Saint Ferréol/Ulmet lobes, that forms an incised valley fill up to $20 \mathrm{~ms}$ (ca. $18 \mathrm{~m}$ ) deep and several km wide (Figs. 3, 4B, 4C, 5). Seismic facies are discontinuous and chaotic, they become more continuous along both sides of the cut-and-fill structure. We interpret this newly described seismic unit as the result of the transgressive fluvial infill of a major distributary of the Rhone, the more continuous seismic facies possibly corresponding to delta plain deposits. As this unit was neither cored nor dated, we can only assume that it formed around the Preboreal (after $10.5 \mathrm{kyr}$ cal. BP, the age of the ERDC in this area, Berné et al., 2007), in relation with a phase of increasing rate of relative sea-level rise. 
Surface D500, is a regional surface observed through the whole seismic database, with alternating low and high amplitude reflections (Figs. 3-5). It is characterized by toplap and onlap (landward) and downlap (seaward) terminations. Nonetheless, the dip angles of various reflections are low and stratal terminations are difficult to identify. D500 displays an overall planar, locally slightly undulated, morphology. This surface is dipping seaward at very low angle $\left(<0.5^{\circ}\right)$. In the central area of the shelf, D500 outcrops and merges with D600 (see below) (Fig. 3). In the easternmost study area, D500 is merged with the sequence boundary of the LGM (D200) (Figs. 3-5). On the basis of stacking patterns and sedimentary facies (see section 4.2), D500 is interpreted as a flooding surface.

Seismic U500 is an acoustically semi-transparent seismic facies with faint sub-parallel reflections (Figs. 3-5). U500 forms a shore parallel prismatic body with a maximum thickness of ca. $13 \mathrm{~m}$, and thinning seaward (Fig. 6A). Its proximal position (with respect to U400), as well as onlap terminations of its internal reflectors, support an interpretation as a transgressive parasequence. Radiocarbon dates of the uppermost part of this seismic unit (ca. 8-

$7.8 \mathrm{kyr}$ cal. BP) also supports this interpretation (Fig. 7; Table 1). The shore-parallel geometry of this unit contrasts with that of U610 (see below) and will be discussed later.

Surface D600, the upper boundary of seismic U500, corresponds to a planar surface dipping very gently seaward. It is characterized by a moderate amplitude reflection and has a very distinct downlapping trend (Figs. 3-5). In the central area of the shelf, D600 outcrops and merges with D610 (see paragraph below) (Fig. 3). The age of D600 is determined from ${ }^{14} \mathrm{C}$ dates in several samples (cores RHS-KS40, RHS-KS54, and RHS-KS55) retrieved beneath and above this surface, as close to the contact as possible (Fig. 7; Table 1). ${ }^{14} \mathrm{C}$ dates constrain the age of D600 between ca. 7.8-5.6 kyr cal. BP. In terms of seismic/sequence and chronostratigraphy, D600 represents a maximum flooding surface (MFS) that marks the time of maximum landward shift of the shoreline, separating backstepping units of the TST (D600 
underlies the retrogradational unit U500) from prograding units (D600 overlies the progradational unit U600) of the Highstand Systems Tract (HST). We will discuss later the lithologic nature of this surface and its age.

Seismic U600 displays prograding tangential clinoforms, with relatively high amplitude, and low dip angle $\left(<0.5^{\circ}\right)$ (Figs. 4, 5). In our study area, U600 forms a prismatic body thickening landward and thinning progressively seaward and eastward. The maximum thickness of U600, in front of the Beauduc spit (equidistant from the Petit Rhone and Grand Rhone outlets), is around $10 \mathrm{~m}$ (Fig. 6B). Radiocarbon dates indicate deposition between ca. 5.6-1 kyr cal. BP (Fig. 7; Table 1). U600 corresponds to the marine component (i.e., prodelta) of the St Ferréol and Ulmet lobes, whose phases of maximum deltaic progradation are dated between 2.82 kyr cal. BP from onshore studies (Vella et al., 2008).

Surface D610 is a regional surface marked by downlap and toplap terminations. Again, due to very low dip angles of surfaces and internal reflections, such terminations are difficult to detect on seismic profiles. D610 is an overall planar surface dipping very gently seaward (Figs. 4, 5). D610 outcrops in the central and western part of the inner shelf (Fig. 3). D610 is also marked by the presence of a gas front (top of gas wipeout) situated seaward of the historical "Bras de Fer" outlet (Arnaud-Fassetta, 1998).

Seismic U610 displays tangential clinoforms with high amplitude (Fig. 4). It is a prismatic body thickening landward and thinning rapidly seaward and westward. The depocentre of U610 is mainly identified in front of the modern Roustan lobe, with a maximum thickness of ca. $5 \mathrm{~m}$ (Fig. 6C). Radiocarbon dates indicate deposition between approximately 1 kyr cal. BP and $280 \mathrm{yr}$ cal. BP (Fig. 7; Table 1). U610 is interpreted as a prodeltaic unit related to the synchronous, then subsequent, activity of the Grand Passon and Bras de Fer distributaries during the Little Ice Age (Arnaud-Fassetta, 1998). However, on our seismic data, there is no 
evidence for two distinct deltaic lobes in front of the Grand Passon and Bras de Fer distributaries.

Seismic U610a is a coeval unit of U610, only observed along the most proximal seismic profiles in the Beauduc area (Fig. 4D). It could correspond to the position of a western distributary of the "Rhône de Bras de Fer" Channel, named the "Rhône de Galabert" Channel. Internal reflections are parallel and continuous with downlap terminations (the upper terminations are situated beyond the landward boundary of our seismic investigation, in very shallow waters). This seismic sub-unit overlies the St Ferreol lobe (U600), the bounding surface between the two being labelled D610a.

Surface D620 is only observed in the easternmost part of the study area, in front of the Grand Rhone mouth. It is characterized by downlap terminations and crops out to the west of the Bras de Fer paleo-mouth (Figs. 4, 5).

Seismic U620 has a seismic facies similar to that of unit U610 (Figs. 4, 5). U620 is wedgeshaped, thinning rapidly seaward and westward. The depocentre of U620 is clearly located in front of the modern Grand Rhone mouth (Roustan) with a maximum thickness of $20 \mathrm{~m}$ (Fig. 6D). In detail, this unit can be sub-divided into 3 sub-units (U620a, U620b, U620c, Figs. 3-5), displaying similar internal architecture and stratal terminations. These sub-units have relatively limited lateral extent, and different position with respect to the present Grand Rhone mouth. A multi-proxy analysis of core RHS-KS57 indicates that deposition of U620a started after 1711 AD (Fanget et al., 2013), which correlates to a period when the "Grand Rhône” Channel was divided into three distributaries (Piémanson, Roustan, and Pégoulier). Similarly, the age model and faunal assemblages (Fanget et al., 2013) clearly indicate that U620b corresponds to the activity of the Pégoulier distributary, which was the only outlet of the Rhone between 1855-1892 AD. Finally, U620c corresponds to the "modern" Rhone prodelta (Roustan), active since 1892 AD. 
The overall seismic architecture of the Rhone subaqueous delta is illustrated by a synthetic profile (strike-oriented) covering the entire inner-shelf (Fig. 3). The main characteristics of seismic discontinuities and seismic units are also synthesized in Table 2.

\subsection{Sedimentary facies and environments}

Three sedimentary facies are identified from eleven studied cores on the basis of lithofacies, sedimentary structures, bioturbation, and color that reflects, in this context, the content in organic carbon (Figs. 7, 8; Table 3). In the following sections, the main facies characteristics and their environmental interpretation are described.

\subsubsection{Facies 1}

\subsubsection{Description}

Facies 1 (Figs. 7, 8A-A'; Table 3) consists of alternating silt (or rarely very fine to fine sand) and grayish silty clay laminae (in the sense of Campbell, 1967). These very thin and thin laminae (mm to few $\mathrm{cm}$ thick) are commonly bounded by an erosional surface. They can be isolated or in groups that make up laminasets (in the sense of Campbell, 1967). These primary structures are sometimes hidden by bioturbation. Laminae thinner than $2 \mathrm{~cm}$ show parallel or undulated laminations highlighted by the accumulation of dark minerals. In laminae thicker than $2 \mathrm{~cm}$, no sedimentary structures are found. Facies 1 forms intervals ranging from $8 \mathrm{~cm}$ to 240 cm, within cores RHS-KS22, RHS-KS39, RHS-KS40, RHS-KS54, and RHS-KS55

(Fig. 7). 


\subsubsection{Interpretation}

On seismic profiles, Facies 1 corresponds to two different settings, (a) the transgressive parasequences reached in the distal part of the study area (seismic U500), and (b) the recentmost proximal seismic facies of U600, U610a and U620.

Considering the erosional base and rhythmic pattern of silty/sandy laminae of Facies 1 , as well as the physiographic setting where they are found, we interpret them as tempestites (Hayes, 1967) formed in a lower to middle shoreface (prodelta) environment during storm decelerating flows (Myrow, 1992; Myrow and Southard, 1996; Pérez-López and PérezValera, 2012). This interpretation will be discussed in section 5.3.

\subsubsection{Facies 2}

\subsubsection{Description}

Facies 2 (Figs. 7, 8B-B'; Table 3) is made of abundant shells and shell debris in a grayish silty clay matrix. Turritella sp. and a number of bivalves (e.g., Acanthocardia echinata, Arca tetragona, Nucula sp.) are found. In cores RHS-KS40 and RHS-KS51, round pebbles (about $1 \mathrm{~cm}$ in diameter) are observed. These pebbles are encrustated by bryozoans, red algae and serpulids. In Facies 2, a highly diverse and abundant benthic microfauna is also observed, with benthic foraminifera (e.g., Cibicides lobatulus, Cassidulina carinata, Elphidium spp., Textularia agglutinans) and ostracods (e.g., Carinocythereis carinata, Cytheropteron monoceros, Loxoconcha spp., Pterigocythereis jonesii), assigned to a variety of environments, ranging from infra-littoral (upper shoreface) to epi-bathyal (lower shoreface to prodelta/offshore) settings (mixed microfaunal assemblages/reworked interval). Facies 2 
shows a clear bimodal sediment distribution (coarse grained fraction is composed of biogenic/siliciclastic material embedded in a silty clay matrix) and an overall fining upward trend. Occasionally, we can observe a bipartition in coarse-grained and fine-grained sediments (RHS-KS40 and RHS-KS51). This facies forms relatively thin intervals, ranging from $20 \mathrm{~cm}$ to $80 \mathrm{~cm}$ in thickness, only observed in the lowest part of the most distal cores (Fig. 7).

\subsubsection{Interpretation}

Facies 2 separates transgressive deposits of seismic unit U500 (tempestites, Facies 1) from highstand deposits of U600 (prodeltaic muds, Facies 3). It corresponds to the position of the Maximum Flooding Surface (D600). The age of this condensed interval is comprised between ca. 7.8-5.6 kyr cal. BP. We will discuss later the apparent paradox of its coarse-grained lithology (see Section 5.1).

\subsubsection{Facies 3}

This facies corresponds to highly bioturbated silty clays. Based on absence or presence of colour banding, we distinguished sub-facies $3 \mathrm{a}$ (without colour banding) and sub-facies $3 \mathrm{~b}$ (with colour banding).

\subsubsection{Description}

\section{Facies 3a}


Based on the abundance of hydrotroilite (hydrous ferrous sulfide), we divided sub-facies $3 \mathrm{a}$ into two sub-facies: sub-facies 3a1 (low hydrotroilite content) and sub-facies 3a2 (high hydrotroilite content).

Sub-Facies 3a1 (Figs. 7, 8C-C'; Table 3) consists of beige silty clay. Bioturbation is abundant and sediment is structureless. Some diffuse veneers of yellowish lighter levels are observed, as well as spots of darker sediments (rich in hydrotroilite, clearly obliterated by bioturbation). Scattered bryozoan debris, shells or shell fragments are found. Biogenic material is mainly made of Turritella sp., and to a minor extent, of bivalves. Facies 3a1 ranges from $85 \mathrm{~cm}$ to $200 \mathrm{~cm}$ in thickness. It is observed in all the distal cores and in the lowest part of the proximal cores RHS-KS53 and RHS-KS52 (Fig. 7).

Sub-Facies 3a2 (Figs. 7, 8D-D'; Table 3) consists of grayish and beige silty clay. The sediment is characterized by abundant hydrotroilite and bioturbation. Facies $3 \mathrm{a} 2$ ranges from $80 \mathrm{~cm}$ to $480 \mathrm{~cm}$ in thickness, and is observed in all the studied cores. Facies $3 \mathrm{a} 2$ is only absent in the two shallow-water cores RHS-KS22 and RHS-KS39 (Fig. 7).

\section{Facies 3b}

Facies 3b (Figs. 7, 8E-E'; Table 3) is composed of silty clay, with abundant colour banding. Colour bands vary from dark, grey, brownish and beige, with bioturbation sometimes mixing the colors from two adjacent bands. Silt (or rarely very fine sand) laminae and few silt or very fine sand beds (in the sense of Campbell, 1967) are observed within this facies. These primary structures are commonly bounded by an erosional surface. Facies $3 \mathrm{~b}$ ranges from $80 \mathrm{~cm}$ to $600 \mathrm{~cm}$ in thickness (Fig. 7). It is observed within all proximal cores, and in the uppermost part of the distal core RHS-KS27, which is located in front of the modern Grand Rhone mouth (Roustan). 


\subsubsection{Interpretation}

Facies $3 \mathrm{a}$ (including sub-facies $3 \mathrm{a} 1$ and $3 \mathrm{a} 2$ ) and $3 \mathrm{~b}$ correspond in seismic facies to the prograding deposits of U600, U610, and U620, which are related to the successive activity of the paleo-Rhone Channels. Radiocarbon dates bracketed these facies between $5.6 \mathrm{kyr}$ cal. BPpresent-day (Fig. 7). Facies 3a and $3 \mathrm{~b}$ are typical facies associations observed in prodeltaic settings of the Rhone (Aloïsi and Monaco, 1980; Chassefiere, 1990; Touzani, 1998; Touzani and Giresse, 2002) and elsewhere (Anderson et al., 2004; Amorosi et al., 2009; Truong et al., 2011). The sediments are made of mud and rare marine gastropods Turritella sp. or benthic foraminera (e.g., Ammonia tepida, Bulimina elongata, Nonionella turgida) and ostracods (e.g., Neocytherideis fasciata, Paradoxostoma sp., Pontocythere elongata) that are typical of a shallow water setting. Occasional continental (fluvial) influence is testified by rare freshwater ostracods (e.g., Candona sp., Ilyocypris sp., Darwinula stevensoni) and coastal benthic foraminifera belonging to the genus Elphidium. Authigenic minerals generated by sulfate reduction (hydrotroilite) can be related to both high sedimentation rate, inducing reducing conditions, and high organic matter input. Facies $3 \mathrm{~b}$ is characterized by spectacular colour banding that does not correspond to any significant variation in grain-size. The good preservation of colour bands suggests occasional dysaerobic to anaerobic conditions, and/or high sedimentation rate preventing bioturbation (Stow et al., 1996). These conditions are possible in a proximal prodeltaic environment. Different colours are probably linked to seasonal changes in the detritus source (Touzani, 1998; Beaudouin et al., 2005) or to floods generated in the different sub-basins of the Rhone watershed (Buscail et al., 2011). For instance, the uppermost $20 \mathrm{~cm}$ of core RHS-KS22, and the uppermost $10 \mathrm{~cm}$ of core RHSKS57 (Fanget et al., 2013), which are characterized by a greyish colour, correspond to the June 2008 flood of the Rhone River (peak discharge of $4156 \mathrm{~m}^{3} \mathrm{~s}^{-1}$ ). This flood event 
occurred after heavy rains over the Durance drainage basin (French Southern Alps), and resulted in deposition of up to $30 \mathrm{~cm}$ of unconsolidated muddy sediments in the vicinity of the Rhone mouth (Cathalot et al., 2010).

\section{Discussion}

\subsection{Significance of key surfaces of the Rhone subaqueous delta}

The terminology of flooding surfaces has been the subject of a large number of studies, and has fuelled the debate on sequence stratigraphy (see review by Cattaneo and Steel, 2003). Our data set provides geometric, lithologic and chrono-stratigraphic constraints about the nature of key surfaces that characterize the Rhone subaqueous delta. In this area, two key surfaces can be followed regionally at the seismic scale. They were previously described by Labaune et al. (2005), but neither characterized from a lithologic point of view nor dated through ${ }^{14} \mathrm{C}$ analysis. Our new data highlight that these key surfaces correspond to a marked lithological change on core data, and to distinct eustatic/climatic events.

D500 is a flooding surface that separates two backstepping parasequences: (a) the Younger Dryas/Preboreal transgressive parasequence (unit U400/U450) and (b) the early Holocene deposits of U500. From a lithologic point of view, this surface corresponds, at the position of our cores, to the transition between (a) fine to medium sands of Unit 400/450 (the underlying parasequence) (Fig. 7) and (b) the tempestite facies of the overlying parasequence (U500). Biogenic content is very low, and only few infra-littoral (upper shoreface) benthic foraminifera (mainly represented by Elphidium crispum) are observed. This surface corresponds to a deepening of depositional settings, its erosional nature being clearly visible on seismic profiles, especially to the east. This surface could be named a wave ravinement 
surface (wRs) in the sense of (Swift, 1968), i.e., an erosional surface created and driven by wave erosion of the shoreface and by rising (relative) sea level. The age of D500 can be delimited by (a) to the west, the age of underlying deposits of the ERDC (ca. $10.5 \mathrm{kyr}$ cal. BP) and, (b) to the east, the age of transgressive deposits of unit U500 (ca. $9.0 \mathrm{kyr}$ cal. BP). It must be emphasised, however, that this surface is diachronous and becomes younger landward, in relation with the chronology of relative sea-level rise.

D600 is the youngest flooding surface, and corresponds to the Maximum Flooding Surface (MFS). On seismic profiles, it is defined on the basis of stratal geometries as a downlap surface. From a lithologic point of view, rather than a surface, it corresponds to an interval (20 to $80 \mathrm{~cm}$ thick) characterized by coarse-grained shell hash and pebbles in a siltyclayey matrix (Figs. 7, 8). Its age is bracketed by underlying deposits of U500 (ca. 8.0$7.8 \mathrm{kyr}$ cal. BP) and overlying deposits of U600, dated between ca. 5.6-3.0 kyr cal. BP. Our findings diverge from previously described maximum flooding surfaces, which are considered as condensed intervals of fine-grained sedimentation (Galloway, 1989). In our interpretation, the MFS observed on the Rhone subaqueous delta is a condensed interval, but it incorporates a very coarse fraction of the previous upper shoreface/delta mouth sediments that were left in situ during transgression. The finest fraction was partly winnowed by waves and currents during transgression in coastal to upper shoreface settings. Thus, the condensed interval described here results from a combined transgressive surface of erosion (Posamentier and Vail, 1988) and a MFS. The age of the MFS depends upon the timing of the turnaround between retrogradation and progradation, which is primarily controlled by the position of depocenters (i.e., the position of river mouths), and by climate changes that influenced the sediment load of the Rhone (see next section). As a result, it varies along-strike, as noticed by (Martinsen and Helland-Hansen, 1995). It must be noted that the MFS cannot be dated directly, as it incorporates reworked material. The ages available for this surface correspond 
to the closest overlying and underlying deposits, that post-date (ca. 5.6-3.0 kyr cal. BP) and predate (ca. 8.0-7.8 kyr cal. BP), respectively, the period of formation of this surface. This relatively long time-span (from 2.5-5.0 kyr) reflects the duration of condensation/erosion at a given site. The long boreholes in the delta plain reveal a similar time gap between ca. 8.07.0 kyr cal. BP and ca. $4.7 \mathrm{kyr}$ cal. BP (Amorosi et al., 2013), that represents the time necessary for the infill of the Rhone estuary.

\subsection{Influence of Rapid Climate Changes (RCC) on deltaic lobes}

The Holocene is an Epoch characterized by rapid climate changes (RCC, Mayewski et al., 2004; Wanner et al., 2008; Wanner et al., 2011). More precisely, six cooler intervals have been identified and correlated at the global scale (Fig. 9). In Europe, these cold events (or at least the last and best documented ones) are characterized by intensified rainfalls. On the basis of our data (seismic data and sedimentary facies) and on available information from the Rhone watershed (e.g., Provansal et al., 2003; Magny et al., 2010; Goehring et al., 2011; Arnaud et al., 2012), we can explore the stratigraphic impact of the most recent and best known RCC, the Little Ice Age (LIA) (Matthes, 1939). We will also discuss briefly the $8.2 \mathrm{ka}$ event (Alley et al., 1997).

\subsubsection{Stratigraphic signature of the 8.2 ka cold event}

The 8.2 ka event was the most prominent short-lived climate perturbation recorded during the Holocene. It was characterized by an abrupt cooling of $5-7^{\circ} \mathrm{C}$ in Greenland (Alley et al., 1997; Alley and Ágústsdóttir, 2005). In Europe, the 8.2 ka event is generally marked by a decrease of summer temperatures on the order of $1^{\circ} \mathrm{C}$. In the Rhone watershed, this event is also 
marked by increased rainfall and higher lake levels (Magny et al., 2003; Magny and Begeot, 2004). From a stratigraphic point of view, this event has been identified in some deltaic/estuarine systems in the form of backstepped bay head deltas (formed in response to a pulse of sea-level rise) (Rodriguez et al., 2010) or as regressive events (due to increased sediment flux) (Amorosi et al., 2009). In the Rhone delta plain, a distinct parasequence, dated at ca. $8.2 \mathrm{kyr}$ cal. BP was described by Amorosi et al. (2013) on a long borehole. In our distal (prodeltaic) study area, on the basis of chrono-stratigraphic constraints, this parasequence is represented by tempestites or a thin, fine-grained interval, observed on cores below the MFS (D600). Because of greater water depth in comparison with the parasequence described below the delta plain by Amorosi et al. (2013), this time interval is not represented, on our data set, by a distinct change in depositional environments.

\subsubsection{Stratigraphic signature of the Little Ice Age (LIA) cold event}

In contrast with the 8.2 ka event, the LIA has a clear signature in our study area. In the Rhone catchment area, the LIA is known as a period of Alpine glacier advance (Ivy-Ochs et al., 2009; Goehring et al., 2011), high lake levels due to increased river runoff (Magny et al., 2010), marked increase of Rhone floods (as mentioned in historical archives and measured along the stream since 1500 AD) (Pichard, 1995), and higher soil erosion (Simonneau et al., 2013). In the Rhone delta plain, it was proposed that the Bras de Fer lobe would be the result of increased runoff during the LIA. For instance Provansal et al. (2003) estimated rapid progradation in relation with increased frequency of floods between 1668-1688 AD. On our data set, two distinct prodeltaic lobes (seismic units U610 and U610a) are identified from seismic data at the outlet of the "Rhône de Bras de Fer" and "Rhône de Grand Passon" Channels (Figs. 4, 5; seismic unit U610) and at the outlet of the "Rhône de Galabert" Channel 
(seismic unit U610a). These lobes are dated between ca. 1 000-280 yr cal. BP (or ca. 950$1670 \mathrm{AD}$ ) on cores. This time interval is slightly offset (by about $300 \mathrm{yr}$ ) with respect to the age of the LIA (1250-1850 AD, Wanner et al., 2011). The relatively old age of initiation of these lobes (compared to the onset of the LIA around $1250 \mathrm{AD}$ ) could be explained by an early phase of climate deterioration in the western Alps. This hypothesis is supported by observed advance of the Rhone glacier, which was initiated around 1000 AD (Goehring et al., 2011), high level of the Bourget Lake initiating around 1200 AD (Arnaud et al., 2012), and increased detrital sedimentation in the delta plain since 1250 AD (Bruneton et al., 2001; Provansal et al., 2003) (Fig. 9). Interestingly, a similar increase of delta outbuilding is observed during the LIA on the Po modern delta, that is largely fed, as the Rhone, by Alpine glaciers (Correggiari et al., 2005a).

The morphology of the Rhone delta plain is not well known for the first part of the LIA. In contrast, the end of this period is well documented. On the basis of historical maps, borehole data and photo-interpretation, (Arnaud-Fassetta and Provansal, 1999) demonstrated that the Rhone main channel evolved from meandering to a braided system, with the development of coarse-grained islands and several sub-channels evolving rapidly through time. This rapid evolution was linked by these authors to the changes that affected the nearby tributaries of the Rhone. When comparing historical maps to the position of prodeltaic depocenters before the main avulsion dated to $1711 \mathrm{AD}$, there is a good match between paleo-channels and paleoprodeltaic lobes (Fig. 6). Indeed, the early development of the Rhone delta, in response to slow-down of sea-level rise, and its evolution until ca. $1.0 \mathrm{kyr}$ cal. BP, was under the influence of wave and wind-driven currents shaping the onshore (beach ridges) and offshore sediments into linear and shore parallel deposits (Fig. 6, seismic units U500 and U600). During periods of increased sediment supply that took place during the cold and humid phases of the LIA, several depocenters are recognized in the offshore part of the Rhone delta (seismic 
unit U610 and U610a). Following the avulsion of "Rhône de Bras de Fer" Channel and formation of the "Grand Rhône" Channel in 1711 AD, the stream became progressively “anthropogenized" by dyke construction since 1855 AD and damming since 1950 AD, with much lower sediment supply and return to present wave-dominated morphology.

\subsection{Tempestites, turbidites or flood deposits}

On the basis of sedimentary structures and physiographic setting, we have proposed that Facies 1 is the product of storm induced processes (tempestites). In the rock record, however, tempestites are difficult to distinguish from turbidites because they both display rhythmic patterns and graded beds with erosional bases (Seilacher and Aigner, 1991). It could be argue that Facies 1 results from (a) hyperpycnal flows generated at the river mouth or (b) mass failure of the delta front evolving into a gravity flow. We consider these interpretations as very unlikely because (a) the Rhone is a large river with a relatively steady flow regime, to the opposite of "dirty" small Mediterranean rivers prone to generate hyperpycnal flows (Mulder and Syvitski, 1995), and (b) it is unlikely that a mass failure may propagate along large distances and evolve into a diluted turbulent flow in a physiographic context where slope is less than $1^{\circ}$.

Another interpretation could be that silty/sandy laminae of Facies 1 result from increased supply of coarser material during river floods. However, according to most studies, flood deposits are rather preserved as fine-grained intervals (high percentage of clay compared to preceding seabed sediment; Sommerfield and Nittrouer, 1999; Wheatcroft and Borgeld, 2000; Wheatcroft and Drake, 2003; Drexler and Nittrouer, 2008). This is also what we observe on cores RHS-KS22 and RHS-KS57 where the deposits of the June 2008 flood of the Rhone 
River correspond to a $20 \mathrm{~cm}$-thick and $10 \mathrm{~cm}$-thick deposits of silty clay, respectively (see Section 4.2.3.).

For these reasons, we favour the "tempestite" hypothesis. In contrast with flood deposits, periods of unusually large storms on the Eel margin are marked by an increase in the mass of medium-coarse silt fractions (20-63 $\mu \mathrm{m})$ (Drake, 1999). The thinner horizontal laminae (up to $2 \mathrm{~cm}$-thick) indicate deposition under traction whereas the thicker laminae might result from density flows occasionally generated at the mouth of the Grand Rhone, as observed by Maillet et al. (2006). Facies 1 has a broad lateral extent (Fig. 7) but there is no evidence for Hummocky Cross-Stratification (HCS), which represents an important element to identify storm deposits (Swift et al., 1983; Duke et al., 1991; Myrow, 1992; Myrow and Southard, 1996). On the other hand, it is very rare to identify medium-scale sedimentary structures in marine cores and unconsolidated sediments (Immenhauser, 2009). It has been observed on the Eel Margin that tempestites do not leave a preserved record on the muddy shelf except in association with wave-supported gravity flows that occur during floods, when the availability of fined-grained sediment is much higher than usual (Traykovski et al., 2000). A similar scenario is likely on the Rhone margin, where "wet storms" resulting from ESE storm waves combine with flood events. In a geological perspective, the importance of such wet storms when huge rain falls (monsoon-like) are associated to major storms/typhoons is likely to be very important. Additionally, it is likely that these tempestites are better preserved within transgressive contexts along the retreat path of deltaic systems (as observed in our case), due to increasing accommodation and rapid burial, whereas they will be reworked into condensed intervals within other contexts.

\section{Conclusions}


The late Holocene stratigraphic architecture and lithofacies distribution of the Rhone subaqueous delta result from a complex interaction between glacio-eustatic sea-level change and changes of sediment fluxes controlled by climate. The recent most architecture of this system is strongly influenced by human activity.

The architecture of the subaqueous delta consists in parasequence (separated by flooding surfaces marking an increase of water depth) and switched prodelta lobes separated by erosional surfaces. These wedges display (1) overall backstepping and westward-migrating geometry during the early Holocene, and (2) overall eastward shift during the middle and late Holocene. The westward backstepping of early Holocene parasequences can be interpreted as a case of oblique retreat as described by McBride and Moslow (1991). Due to combined effect of relative sea-level rise and westward sediment transport through wind-driven marine currents, the rive outlets migrated obliquely during the early Holocene. Later, their eastward migration during global high sea-level was probably favoured by higher accommodation within the thick and subsiding Plio-Quaternary Rhone valley fill.

Regionally, one key surface is the flooding surface associated with the increased relative sealevel rise that occurred at the transition between the Younger Dryas and the Preboreal. The Maximum Flooding Surface is characterized by a coarse-grained interval, incorporating reworked shoreface material within a matrix of fine-grained silt and clays with mixed faunal assemblages ranging from infra-littoral to epi-bathyal settings. This lithology results from the importance of condensation and/or erosion within deltaic systems. Despite the large amount of sediment supplied in deltaic settings, some parts of prodeltas can be subject to erosion by oceanic processes due to the shift of distributary channels. In the case of the Rhone, this phenomenon results in the deposition of sedimentary wedges bounded by erosion surfaces that mimic flooding surfaces, even though there are not associated with any change in water depth or lithology. 
The last two major rapid climate changes have a distinct stratigraphic signature. During the 8.2 ka event, he tempestite sedimentary facies observed in our cores is interpreted as the signature of increased sediment supply and major "wet storms". It is coeval with the transgressive parasequence observed in the delta plain. Such tempestites might represent combined storm and wave events within transgressive systems.

Two deltaic lobes are associated with the Little Ice Age. Their age is slightly offset with the age of initiation and termination of the LIA, but they are in phase with other records of climate deterioration during the last $1.0 \mathrm{kyr}$ in the Rhone watershed.

The modern Rhone subaqueous delta is considered as a typical example of moderately wavedominated delta (Bhattacharya and Giosan, 2003). However, during the late Holocene, it evolved from wave-dominated (from ca. 5.0-1.0 kyr cal. B.P.) to fluvial dominated around the Little Ice Age (from about 950-1711 AD), and finally wave-dominated during the most recent most. We suggest that these changes are related to sediment supply that is directly influenced by (rapid) climate changes.

\section{Acknowledgements}

Seismic data and sediment cores were acquired during cruise RHOSOS (2008) on board R/V "Le Suroitt". We thank the scientific parties as well as the captain and crew of this cruise together with the Genavir technical staff. We thank the Laboratoire de Mesure du Carbone 14, UMS 2572, ARTEMIS in Saclay for ${ }^{14} \mathrm{C}$ measurements by SMA in the frame of the National Service to CEA, CNRS, IRD, IRSN and Ministère de la Culture et de la Communication. This work was partly supported by the French "Mistrals-Paleomex" project and ANR "Extrema" (contract number ANR-06-VULN-005). We are grateful to Bertil Hebert and Julie Billy at CEFREM (University of Perpignan), and Estelle Théreau, Gilbert Floch, Mickaël Rovere and 
Angelique Roubi at IFREMER for their technical support. The authors would like to thank

Alessandro Amorosi, an anonymous reviewer, and the editor Jasper Knight for their stimulating reviews that improved the manuscript.

\section{References}

Alley, R.B., Ágústsdóttir, A.M., 2005. The 8k event: cause and consequences of a major Holocene abrupt climate change. Quaternary Science Reviews 24, 1123-1149.

Alley, R.B., Mayewski, P.A., Sowers, T., Stuiver, M., Taylor, K.C., Clark, P.U., 1997. Holocene climatic instability: A prominent, widespread event 8200 yr ago. Geology 25, 483-486.

Aloïsi, J.C., 1986. Sur un modèle de sédimentation deltaïque: contribution à la connaissance des marges passives. Unpublished Doctoral Thesis, University of Perpignan, $162 \mathrm{p}$.

Aloïsi, J.C., Auffret, G.A., Auffret, J.P., Barusseau, J.P., Hommeril, P., Larsonneur, C., Monaco, A., 1977. Essai de modélisation de la sédimentation actuelle sur les plateaux continentaux français. Bulletin de la Société Géologique de France 19, 183-195.

Aloïsi, J.C., Monaco, A., 1980. Etude des structures sédimentaires dans les milieux deltaïques (Rhône). Apport à la connaissance des conditions de sédimentation et de diagénèse. Comptes Rendus de 1'Académie des Sciences, Série D, Paris 290, 879-882.

Aloïsi, J.C., Monaco, A., Thommeret, J., Thommeret, Y., 1975. Evolution paléogéographique du plateau continental languedocien dans le cadre du Golfe du Lion. Analyse comparée des données sismiques, sédimentologiques et radiométriques concernant le Quaternaire récent. Revue de Géologie Dynamique et de Géographie Physique 17, 13 22.

Amorosi, A., Ricci Lucchi, M., Rossi, V., Sarti, G., 2009. Climate change signature of smallscale parasequences from Lateglacial-Holocene transgressive deposits of the Arno valley fill. Palaeogeography, Palaeoclimatology, Palaeoecology 273, 142-152.

Amorosi, A., Rossi, V., Vella, C., 2013. Stepwise post-glacial transgression in the Rhône Delta area as revealed by high-resolution core data. Palaeogeography, Palaeoclimatology, Palaeoecology 374, 314-326.

Anderson, J.B., Rodriguez, A., Abdulah, K.C., Fillon, R.H., Banfield, L.A., McKeown, H.A., Wellner, J.S., 2004. Late Quaternary Stratigraphic evolution of the northern Gulf of Mexico margin: a synthesis. In: Anderson, J.B., Fillon, R.H. (Eds.), Late Quaternary Stratigraphic evolution of the northern Gulf of Mexico margin. SEPM (Society for Sedimentary Geology), Tulsa, pp. 1-23.

Arnaud-Fassetta, G., 1998. Dynamiques fluviales holocènes dans le delta du Rhône. PhD Thesis, Université de Provence, Aix en Provence, 329 pp.

Arnaud-Fassetta, G., 2002. Geomorphological records of a flood-dominated regime in the Rhône delta (France) between the 1st century and the 2nd century AD. What correlations with the catchment paleohydrology? Geodinamica Acta 15, 79-92.

Arnaud-Fassetta, G., Provansal, M., 1999. High frequency variations of water flux and sediment discharge during the Little Ice Age in the Rhone delta (France). Relationship to the catchment area. Developments in Hydrobiologia 410, 241-250. 
Arnaud-Fassetta, G.A., de Beaulieu, J.L., Suc, J.P., Provansal, M., Williamson, D., Leveau, P., Aloïsi, J.C., Gadel, F., Giresse, P., Oberlin, C., Duzer, D., 2000. Evidence for an early land use in the Rhône delta (Mediterranean France) as recorded by late Holocene fluvial paleoenvironments (1640-100 BC). Geodinamica Acta 13, 377-389.

Arnaud, F., Révillon, S., Debret, M., Revel, M., Chapron, E., Jacob, J., Giguet-Covex, C., Poulenard, J., Magny, M., 2012. Lake Bourget regional erosion patterns reconstruction reveals Holocene NW European Alps soil evolution and paleohydrology. Quaternary Science Reviews 51, 81-92.

Bassetti, M.A., Berné, S., Jouet, G., Taviani, M., Dennielou, B., Flores, J.A., Gaillot, A., Gelfort, R., Lafuerza, S., Sultan, N., 2008. The 100-ka and rapid sea level changes recorded by prograding shelf sand bodies in the Gulf of Lions (western Mediterranean Sea). Geochemistry, Geophysics, Geosystems 9, Q11R05, doi: $10.1029 / 2007 \mathrm{gc001854.}$

Beaudouin, C., Suc, J.P., Cambon, G., Touzani, A., Giresse, P., Pont, D., Aloïsi, J.C., Marsset, T., Cochonat, P., Duzer, D., Ferrier, J., 2005. Present-day rhythmic deposition in the Grand Rhone prodelta (NW Mediterranean) according to highresolution pollen analyses. Journal of Coastal Research 21, 292-306.

Berendsen, H.J.A., Stouthamer, E., 2000. Late Weichselian and Holocene palaeogeography of the Rhine-Meuse delta, The Netherlands. Palaeogeography, Palaeoclimatology, Palaeoecology 161, 311-335.

Berné, S., Jouet, G., Bassetti, M.A., Dennielou, B., Taviani, M., 2007. Late Glacial to Preboreal sea-level rise recorded by the Rhone deltaic system (NW Mediterranean). Marine Geology 245, 65-88.

Bhattacharya, J.P., 2006. Deltas. In: Posamentier, H.W., Walker, R.G. (Eds.), Facies Models Revisited. SEPM Special Publication, pp. 237-292.

Bhattacharya, J.P., Giosan, L., 2003. Wave-influenced deltas: geomorphological implications for facies reconstruction. Sedimentology 50, 187-210.

Bhattacharya, J.P., Walker, R.G., 1992. Deltas. In: Walker, R.G., James, N.P. (Eds.), Facies Models: Response to Sea-Level Change. Geological Association of Canada, St Johns, pp. 157-177.

Boyer, J., Duvail, C., Le Strat, P., Gensous, B., Tesson, M., 2005. High resolution stratigraphy and evolution of the Rhone delta plain during Postglacial time, from subsurface drilling data bank. Marine Geology 222-223, 267-298.

Bruneton, H., Arnaud-Fassetta, G., Provansal, M., Sistach, D., 2001. Geomorphological evidence for fluvial change during the Roman period in the lower Rhone valley (southern France). Catena 45, 287-312.

Buscail, R., Bossard, N., Fanget, A.S., Jeanty, G., Desmousseaux, M., Sotin, C., Arnaud, M., Berné, S., 2011. Enregistrements récentes de différents types de dépôts de crues du Rhône : prodelta à 45 m - année 2008, Colloque Final ANR EXTREMA, Saint-PaulLez-Durance, France.

Campbell, C.V., 1967. Lamina, laminaset, bed and bedset. Sedimentology 8, 7-26.

Cathalot, C., Rabouille, C., Pastor, L., Deflandre, B., Viollier, E., Buscail, R., Grémare, A., Treignier, C., Pruski, A., 2010. Temporal variability of carbon recycling in coastal sediments influenced by rivers: assessing the impact of flood inputs in the Rhône River prodelta. Biogeosciences 7, 1187-1205.

Cattaneo, A., Correggiari, A., Langone, L., Trincardi, F., 2003. The late-Holocene Gargano subaqueous delta, Adriatic shelf: Sediment pathways and supply fluctuations. Marine Geology 193, 61-91.

Cattaneo, A., Steel, R.J., 2003. Transgressive deposits: a review of their variability. EarthScience Reviews 62, 187-228. 
Chassefiere, B., 1990. Mass-physical properties of surficial sediments on the Rhône continental margin: implications for the nepheloid benthic layer. Continental Shelf Research 10, 857-867.

Correggiari, A., Cattaneo, A., Trincardi, F., 2005a. Depositional pattern in the late Holocene Po delta system. In: Bhattacharya, J.P., Giosan, L. (Eds.), River Delta-Concepts, Models, and Examples. SEPM Special Publication, Tulsa, pp. 365-392.

Correggiari, A., Cattaneo, A., Trincardi, F., 2005b. The modern Po Delta system: Lobe switching and asymmetric prodelta growth. Marine Geology 222-223, 49-74.

Drake, D.E., 1999. Temporal and spatial variability of the sediment grain-size distribution on the Eel shelf: the flood layer of 1995. Marine Geology 154, 169-182.

Drexler, T.M., Nittrouer, C.A., 2008. Stratigraphic signatures due to flood deposition near the Rhône River: Gulf of Lions, northwest Mediterranean Sea. Continental Shelf Research 28, 1877-1894.

Dufois, F., Garreau, P., Le Hir, P., Forget, P., 2008. Wave- and current-induced bottom shear stress distribution in the Gulf of Lions. Continental Shelf Research 28, 1920-1934.

Duke, W.L., Arnott, R.W.C., Cheel, R.J., 1991. Shelf sandstones and hummocky crossstratification: New insights on a stormy debate. Geology 19, 625-628.

Fanget, A.S., Bassetti, M.A., Arnaud, M., Chiffoleau, J.F., Cossa, D., Goineau, A., Fontanier, C., Buscail, R., Jouet, G., Maillet, G.M., Negri, A., Dennielou, B., Berné, S., 2013. Historical evolution and extreme climate events during the last 400 years on the Rhone prodelta (NW Mediterranean). Marine Geology 346, 375-391.

Galloway, W.E., 1975. Process framework for describing the morphologic and stratigraphic evolution of deltaic depositional systems. In: Broussard, M.L. (Ed.), Deltas, Models for Exploration. Houston Geological Society, pp. 87-98.

Galloway, W.E., 1989. Genetic stratigraphic sequences in basin analysis I: architecture and genesis of flooding surface bounded depositional units. American Association of Petroleum Geologists Bulletin 73, 125-142.

Gensous, B., Tesson, M., 2003. L'analyse des dépôts postglaciaires et son application à l'étud des séquences de dépôt du Quaternaire terminal sur la plate-forme au large du Rhône (golfe du Lion). Bulletin de la Société Géologique de France 174, 401-419.

Goehring, B.M., Schaefer, J.M., Schluechter, C., Lifton, N.A., Finkel, R.C., Jull, A.J.T., Akçar, N., Alley, R.B., 2011. The Rhone Glacier was smaller than today for most of the Holocene. Geology 39, 679-682.

Gueguen, E., 1995. La Méditerranée Occidentale : un véritable océan. Exemple de segmentation des marges et de hiatus cinématiques. Implications sur les processus d'amincissement crustal., Université de Bretagne Occidentale, Brest, 281 pp.

Guillén, J., Bourrin, F., Palanques, A., Durrieu de Madron, X., Puig, P., Buscail, R., 2006. Sediment dynamics during wet and dry storm events on the Tet inner shelf (SW Gulf of Lions). Marine Geology 234, 129-142.

Hayes, M.O., 1967. Hurricanes as geological agents, south Texas coast. American Association of Petroleum Geologists Bulletin 51, 937-942.

Hsü, K.J., Cita, M.B., Ryan, W.B.F., 1973. The origin of the Mediterranean evaporites. Initial Reports of the Deep Sea Drilling Project, U.S. Government Printing Office 13, 1203 1231.

Immenhauser, A., 2009. Estimating palaeo-water depth from the physical rock record. EarthScience Reviews 96, 107-139.

Ivy-Ochs, S., Kerschner, H., Maisch, M., Christl, M., Kubik, P.W., Schlüchter, C., 2009. Latest Pleistocene and Holocene glacier variations in the European Alps. Quaternary Science Reviews 28, 2137-2149. 
Jouet, G., Berné, S., Rabineau, M., Bassetti, M.A., Bernier, P., Dennielou, B., 2006. Shoreface migrations at the shelf edge and sea-level changes around the Last Glacial Maximum (Gulf of Lions, NW Mediterranean Sea). Marine Geology 234, 21-42.

Kruit, C., 1955. Sediments of the Rhône delta: Grain Size and Microfauna. Mouton and Co, La Haye, 357-555.

L'Homer, A., Bazile, F., Thommeret, J., Thommeret, Y., 1981. Principales étapes de l'édification du delta du Rhône de 7000 B.P. à nos jours ; variations du niveau marin. Oceanis 7, 389-408.

Labaune, C., Jouet, G., Berné, S., Gensous, B., Tesson, M., Delpeint, A., 2005. Seismic stratigraphy of the Deglacial deposits of the Rhone prodelta and of the adjacent shelf. Marine Geology 222-223, 299-311.

Labaune, C., Tesson, M., Gensous, B., 2008. Variability of the transgressive stacking pattern under environmental changes control: Example from the Post-Glacial deposits of the Gulf of Lions inner-shelf, Mediterranean, France. Continental Shelf Research 28, $1138-1152$.

Lofi, J., Rabineau, M., Gorini, C., Berne, S., Clauzon, G., De Clarens, P., Tadeu Dos Reis, A., Mountain, G.S., Ryan, W.B.F., Steckler, M.S., Fouchet, C., 2003. Plio-Quaternary prograding clinoform wedges of the western Gulf of Lion continental margin (NW Mediterranean) after the Messinian Salinity Crisis. Marine Geology 198, 289-317.

Magny, M., Arnaud, F., Holzhauser, H., Chapron, E., Debret, M., Desmet, M., Leroux, A., Millet, L., Revel, M., Vannière, B., 2010. Solar and proxy-sensitivity imprints on paleohydrological records for the last millennium in west-central Europe. Quaternary Research 73, 173-179.

Magny, M., Begeot, C., 2004. Hydrological changes in the European midlatitudes associated with freshwater outbursts from Lake Agassiz during the Younger Dryas event and the early Holocene. Quaternary Research 61, 181-192.

Magny, M., Bégeot, C., Guiot, J., Peyron, O., 2003. Contrasting patterns of hydrological changes in Europe in response to Holocene climate cooling phases. Quaternary Science Reviews 22, 1589-1596.

Maillet, G.M., Vella, C., Berne, S., Friend, P.L., Amos, C.L., Fleury, T.J., Normand, A., 2006. Morphological changes and sedimentary processes induced by the December 2003 flood event at the present mouth of the Grand Rhone River (southern France). Marine Geology 234, 159-177.

Marsset, T., Bellec, V., 2002. Late Pleistocene-Holocene deposits of the Rhône inner continental shelf (France): detailed mapping and correlation with previous continental and marine studies. Sedimentology 49, 255-276.

Martinsen, O.J., Helland-Hansen, W., 1995. Strike variability of clastic depositional systems: does it matter for sequence-stratigraphic analysis? Geology 23, 439-442.

Matthes, F.E., 1939. Report of the Committe on Glaciers, April 1939. Transactions American Geophysical Union 20, 518-523.

Mayewski, P.A., Rohling, E.E., Curt Stager, J., Karlén, W., Maasch, K.A., David Meeker, L., Meyerson, E.A., Gasse, F., van Kreveld, S., Holmgren, K., Lee-Thorp, J., Rosqvist, G., Rack, F., Staubwasser, M., Schneider, R.R., Steig, E.J., 2004. Holocene climate variability. Quaternary Research 62, 243-255.

McBride, R.A., Moslow, T.F., 1991. Origin, evolution, and distribution of shoreface sand ridges, Atlantic inner shelf, U.S.A. Marine Geology 97, 57-85.

Mitchum, R.M., Vail, P.R., Sangree, J.B., 1977. Stratigraphic Interpretation of Seismic Reflection Patterns in Depositional Sequences. In: Payton, C.E. (Ed.), Seismic stratigraphy - Application to hydrocarbon exploration. AAPG Memoir 26, Tulsa, Oklahoma, pp. 117-133. 
Mix, A.C., Bard, E., Schneider, R., 2001. Environmental processes of the ice age: land, oceans, glaciers (EPILOG). Quaternary Science Reviews 20, 627-657.

Myrow, P.M., 1992. Bypass-zone tempestite facies model and proximality trends for an ancient muddy shoreline and shelf. Journal of Sedimentary Petrology 62, 99-115.

Myrow, P.M., Southard, J.B., 1996. Tempestite deposition. Journal of Sedimentary Research 66, 875-887.

Nittrouer, C.A., Kuehl, S.A., DeMaster, D.J., Kowsmann, R.O., 1986. The deltaic nature of Amazon Shelf sedimentation. Geological Society of America Bulletin 97, 444-458.

Oomkens, E., 1970. Depositional sequences and sand distribution in the postglacial Rhône delta complex. In: Morgan, J.P., Shaver, R.H. (Eds.), Deltaic sedimentation, modern and ancient. SEPM (Society for Sedimentary Geology) Special Publication 15, Tulsa, pp. 198-212.

Palanques, A., Durrieu de Madron, X., Puig, P., Fabres, J., Guillén, J., Calafat, A., Canals, M., Heussner, S., Bonnin, J., 2006. Suspended sediment fluxes and transport processes in the Gulf of Lions submarine canyons. The role of storms and dense water cascading. Marine Geology 234, 43-61.

Pérez-López, A., Pérez-Valera, F., 2012. Tempestite facies models for the epicontinental Triassic carbonates of the Betic Cordillera (southern Spain). Sedimentology 59, 646678.

Pichard, G., 1995. Les crues sur le bas-Rhône de 1500 à nos jours. Pour une histoire hydroclimatique. Méditerranée 3-4, 105-116.

Posamentier, H.W., Vail, P.R., 1988. Eustatic controls on clastic deposition II. Sequences and systems tract models. In: Wilgus, C.K., Hastings, B.S., Kendall, C.G.S.C.,

Posamentier, H.W., Ross, C.A., Van Wagoner, J.C. (Eds.), Sea-Level Changes- an Integrated Approach. SEPM Special Publication 42, Tulsa, pp. 125-154.

Pratson, L.F., Nittrouer, C.A., Wilberg, P., Steckler, M.S., Swenson, J., Cacchione, D.A., Karson, J.A., Murray, A.B., Wolinsky, M.A., Gerber, T.P., Mullenbach, B.L., Spinelli, G.A., Fulthorpe, C.S., O'Grady, D.B., Parker, G., Driscoll, N.W., Burger, R.L., Paola, C., Orange, D.L., Field, M.E., Friedrichs, C.T., Fedele, J.J., 2007. Seascape evolution on clastic continental shelves and slopes. In: Nittrouer, C.A., Austin, J.A., Field, M.E., Kravitz, J.H., Syvitski, J.P.M., Wilberg, P. (Eds.), Continental Margin Sedimentation. International Association of Sedimentologists Special Publication, pp. 339-381.

Provansal, M., Vella, C., Arnaud-Fassetta, G., Sabatier, F., Maillet, G., 2003. Role of fluvial sediment inputs in the mobility of the Rhône delta coast (France). Géomorphologie: relief, processus, environnement 4, 271-282.

Rabineau, M., Berne, S., Aslanian, D., Olivet, J.L., Joseph, P., Guillocheau, F., Bourillet, J.F., Ledrezen, E., Granjeon, D., 2005. Sedimentary sequences in the Gulf of Lion: A record of 100,000 years climatic cycles. Marine and Petroleum Geology 22, 775-804.

Rabineau, M., Berné, S., Le Drezen, E., Lericolais, G., Marsset, T., Rotunno, M., 1998. 3D architecture of lowstand and transgressive Quaternary sand bodies on the outer shelf of the Gulf of Lion, France. Marine and Petroleum Geology 15, 439-452.

Reimer, P.J., Baillie, M.G.L., Bard, E., Bayliss, A., Beck, J.W., Blackwell, P.G., Bronk Ramsey, C., Buck, C.E., Burr, G., Edwards, R.L., Friedrich, M., Grootes, P.M., Guilderson, T.P., Hajdas, I., Heaton, T.J., Hogg, A.G., Hughen, K.A., Kaiser, K.F., Kromer, B., McCormac, F.G., Manning, S.W., Reimer, R.W., Richards, D.A., Southon, J., Turney, C.S.M., Van der Plicht, J., Weyhenmeyer, C., 2009. IntCal09 and Marine09 radiocarbon age calibration curves, 0-50,000 years cal BP. Radiocarbon 51, 1111-1150. 
Rey, T., Lefevre, D., Vella, C., 2005. Données nouvelles sur les lobes deltaïques du paléogolfe d'Aigues-Mortes à l'Holocène (Petite Camargue, France). Quaternaire 16, 329-338.

Riboulot, V., Cattaneo, A., Berné, S., Schneider, R.R., Voisset, M., Imbert, P., Grimaud, S., 2012. Geometry and chronology of late Quaternary depositional sequences in the Eastern Niger Submarine Delta. Marine Geology 319-322, 1-20.

Rodriguez, A.B., Simms, A.R., Anderson, J.B., 2010. Bay-head deltas across the northern Gulf of Mexico back step in response to the 8.2 ka cooling event. Quaternary Science Reviews 29, 3983-3993.

Sabatier, F., 2001. Fonctionnement et dynamiques morphosédimentaires du littoral du delta du Rhône, Université d'Aix-Marseille III, 272 pp.

Sabatier, F., Maillet, G., Provansal, M., Fleury, T.J., Suanez, S., Vella, C., 2006. Sediment budget of the Rhone delta shoreface since the middle of the 19th century. Marine Geology 234, 143-157.

Sabatier, F., Suanez, S., 2003. Evolution of the Rhône delta coast since the end of the 19th cetury. Geomorphologie : relief, processus, environnement 4, 283-300.

Saito, Y., 2005. Mega-deltas in Asia: characteristics and human influences. In: Chen, Z.Y., Saito, Y., Goodbred, S.L.J. (Eds.), Mega-deltas of Asia: Geological evolution and human impact. China Ocean Press, Beijing, pp. 1-8.

Saito, Y., Yang, Z., Hori, K., 2001. The Huanghe (Yellow River) and Changjiang (Yangtze River) deltas: a review on their characteristics, evolution and sediment discharge during the Holocene. Geomorphology 41, 219-231.

Schock, S.G., Leblanc, L.R., Mayer, L.A., 1989. Chirp subbottom profiler for quantitative sediment analyses. Geophysics 54, 445-450.

Simonneau, A., Doyen, E., Chapron, E., Millet, L., Vannière, B., Di Giovanni, C., Bossard, N., Tachikawa, K., Bard, E., Albéric, P., Desmet, M., Roux, G., Lajeunesse, P., Berger, J.F., Arnaud, F., 2013. Holocene land-use evolution and associated soil erosion in the French Prealps inferred from Lake Paladru sediments and archaeological evidences. Journal of Archaeological Science 40, 1636-1645.

Sommerfield, C.K., Nittrouer, C.A., 1999. Modern accumulation rates and a sediment budget for the Eel shelf: a flood-dominated depositional environment. Marine Geology 154, 227-241.

Somoza, L., Barnolas, A., Arasa, A., Maestro, A., Rees, J.G., Hernandez-Molina, F.J., 1998. Architectural stacking patterns of the Ebro delta controlled by Holocene highfrequency eustatic fluctuations, delta-lobe switching and subsidence processes. Sedimentary Geology 117, 11-32.

Speranza, F., Villa, I.M., Sagnotti, L., Florindo, F., Cosentino, D., Cipollari, P., Mattei, M., 2002. Age of the Corsica-Sardinia rotation and Liguro-Provençal Basin spreading: new paleomagnetic and Ar/Ar evidence. Tectonophysics 347, 231-251.

Stanford, J.D., Hemingway, R., Rohling, E.J., Challenor, P.G., Medina-Elizalde, M., Lester, A.J., 2011. Sea-level probability for the last deglaciation: A statistical analysis of farfield records. Global and Planetary Change 79, 193-203.

Stow, D.A.V., Reading, H.G., Collinson, J.D., 1996. Deep seas. In: Reading, H.G. (Ed.), Sedimentary Environments. Blackwell, London, pp. 395-453.

Swift, D.J.P., 1968. Coastal erosion and transgressive stratigraphy. Journal of Geology 76, 444-456.

Swift, D.J.P., Figueiredo, A.G., Freeland, G.L., Oertel, G.F., 1983. Hummocky crossstratification and megaripples: a geological double standard? Journal of Sedimentary Petrology 53, 1295-1317. 
Swift, D.J.P., Sears, P.C., Bohlke, B., Hunt, R., 1978. Evolution of a shoal retreat massif, North Carolina Shelf: Inferences from areal geology. Marine Geology 27, 19-42.

Syvitski, J.P.M., Kettner, A.J., Overeem, I., Hutton, E.W.H., Hannon, M.T., Brakenridge, G.R., Day, J., Vorosmarty, C., Saito, Y., Giosan, L., Nicholls, R.J., 2009. Sinking deltas due to human activities. Nature Geoscience 2, 681-686.

Ta, T.K.O., Nguyen, V.L., Tateishi, M., Kobayashi, I., Saito, Y., Nakamura, T., 2002.

Sediment facies and Late Holocene progradation of the Mekong River Delta in Bentre Province, southern Vietnam: an example of evolution from a tide-dominated to a tideand wave-dominated delta. Sedimentary Geology 152, 313-325.

Tanabe, S., Hori, K., Saito, Y., Haruyama, S., Vu, V.P., Kitamura, A., 2003. Song Hong (Red River) delta evolution related to millennium-scale Holocene sea-level changes. Quaternary Science Reviews 22, 2345-2361.

Tesson, M., Posamentier, H.W., Gensous, B., 2000. Stratigraphic organization of Late Pleistocene deposits of the western part of the Rhone shelf (Languedoc shelf) from high resolution seismic and core data. AAPG Bulletin 84, 119-150.

Touzani, A., 1998. L'édification prodeltaïque du Rhône: marqueurs de l'évolution séculaire de la sédimentation, $190 \mathrm{pp}$.

Touzani, A., Giresse, P., 2002. The Rhone River Prodelta: short-term $\left(10^{0}-10^{3}\right.$ Year) sedimentation patterns and human impact. Journal of Coastal Research 18, 102-117.

Traykovski, P., Geyer, W.R., Irish, J.D., Lynch, J.F., 2000. The role of wave-induced densitydriven fluid mud flows for cross-shelf transport on the Eel River continental shelf. Continental Shelf Research 20, 2113-2140.

Trincardi, F., Cattaneo, A., Correggiari, A., 2004. Mediterranean prodelta systems: natural evolution and human impact investigated by Eurodelta. Oceanography 17, 34-45.

Truong, M.H., Nguyen, V.L., Ta, T.K.O., Takemura, J., 2011. Changes in late PleistoceneHolocene sedimentary facies of the Mekong River Delta and the influence of sedimentary environment on geotechnical engineering properties. Engineering Geology 122, 146-159.

Ulses, C., Estournel, C., Bonnin, J., Durrieu de Madron, X., Marsaleix, P., 2008. Impact of storms and dense water cascading on shelf-slope exchanges in the Gulf of Lion (NW Mediterranean). Journal of Geophysical Research 113, doi: 10.1029/2006JC003795.

van Wagoner, J.C., Mitchum, R.M., Campion, K.M., Rahmanian, V.D., 1990. Siliciclastic sequence stratigraphy in well logs, cores and outcrops. Methods in Exploration Series $\mathrm{N}^{\circ}$ 7. American Association of Petroleum Geologists, $55 \mathrm{pp}$.

Vella, C., Fleury, T.J., Gensous, B., Labaune, C., Tesson, M., 2008. Holocene long-sequences and sedimentary discontinuities of the Rhône delta. Cahier de Géographie 6, 159-170.

Vella, C., Fleury, T.J., Raccasi, G., Provansal, M., Sabatier, F., Bourcier, M., 2005. Evolution of the Rhone delta plain in the Holocene. Marine Geology 222-223, 235-265.

Vella, C., Provansal, M., 2000. Relative sea-level rise and neotectonic events during the last 6500yr on the southern eastern Rhône delta, France. Marine Geology 170, $27-39$.

Walker, M., Johnsen, S., Rasmussen, S.O., Popp, T., Steffensen, J.-P., Gibbard, P., Hoek, W., Lowe, J., Andrews, J., Björck, S., Cwynar, L.C., Hughen, K., Kershaw, P., Kromer, B., Litt, T., Lowe, D.J., Nakagawa, T., Newnham, R., Schwander, J., 2009. Formal definition and dating of the GSSP (Global Stratotype Section and Point) for the base of the Holocene using the Greenland NGRIP ice core, and selected auxiliary records. Journal of Quaternary Science 24, 3-17.

Wanner, H., Beer, J., Bütikofer, J., Crowley, T.J., Cubasch, U., Flückiger, J., Goosse, H., Grosjean, M., Joos, F., Kaplan, J.O., Küttel, M., Müller, S.A., Prentice, I.C., Solomina, O., Stocker, T.F., Tarasov, P., Wagner, M., Widmann, M., 2008. Mid- to 
Late Holocene climate change: an overview. Quaternary Science Reviews 27, 17911828.

Wanner, H., Solomina, O., Grosjean, M., Ritz, S.P., Jetel, M., 2011. Structure and origin of Holocene cold events. Quaternary Science Reviews 30, 3109-3123.

Wheatcroft, R.A., Borgeld, J.C., 2000. Oceanic flood deposits on the northern California shelf: large-scale distribution and small-scale physical properties. Continental Shelf Research 20, 2163-2190.

Wheatcroft, R.A., Drake, D.E., 2003. Post-depositional alteration and preservation of sedimentary event layers on continental margins, I. The role of episodic sedimentation. Marine Geology 199, 123-137.

\section{Figure Captions}

Figure 1. Bathymetric map of the Gulf of Lions (based on Berné et al., 2002). Isobath contour line interval is $5 \mathrm{~m}$ from 0 to $160 \mathrm{~m}$ water depth, $100 \mathrm{~m}$ beyond $150 \mathrm{~m}$. Sand distribution is modified from Aloïsi (1986). Retreat paths of the main Rhône (1) and other Rhône distributaries (1w1, 1w2, 1w3, and 1e) during the post-Last Glacial Maximum sea-level rise are based on Berné et al. (2007). The Early Rhone Deltaic Complex (ERDC) is a transgressive parasequence corresponding to a phase of decelerating sea-level rise (Younger Dryas) and increased sediment supply (Preboreal).

Figure 2. Offshore and onshore morphology of the Rhone deltaic system. This map is based on the compilation of Berné et al. (2007) and Vella et al. (2008). The successive shifting of the Rhone distributaries under natural and/or anthropic influence during the Middle and Late Holocene led to the formation of several prodeltaic lobes with (1) remnants of the Early Saint Ferréol delta front; (2) remnants of the Peccais (?) delta front; (3) remnants of the Bras de Fer delta front; (4) remnants of the Pégoulier delta front; (5) modern Roustan delta front. The evolution of the Rhone delta plain during the Holocene (paleo-shoreline, beach ridges and onshore deltaic lobes) are based on L'Homer et al. (1981), Arnaud-Fassetta (1998), Vella 
(1999) and Provansal et al. (2003). Thick lines and black dots correspond respectively to Chirp seismic profiles and sediment cores presented in this study.

Figure 3. (A) Chirp seismic profile across the entire Rhone subaqueous delta (position in Fig. 2), and (B) its interpretation (see text for details). Note the very exaggerated vertical scale.

Figure 4. "Dip" (N-S) chirp seismic profiles across the eastern Rhone subaqueous delta (positions in Fig. 2). See text for details. Note the very exaggerated vertical scale.

Figure 5. "Strike" (W-E) chirp seismic profiles across the eastern Rhone subaqueous delta (positions in Fig. 2). See text for details. Note the very exaggerated vertical scale.

Figure 6. Isopach maps of the main Holocene units identified in the Rhone subaqueous delta. From the base to the top, the seismic units are (A) U500, (B) U600, (C) U610, and (D) U620. Thickness in meters, based on an average acoustic velocity of $1600 \mathrm{~m} \mathrm{~s}^{-1}$ in sediment.

Figure 7. Lithologic description of studied cores (position in Fig. 2). Sedimentary facies identified on the base of visual description and described in the text are indicated to the left of the lithologic logs. AMS ${ }^{14} \mathrm{C}$ dates are mentioned to the right; italic values correspond to age inversions. The ${ }^{14} \mathrm{C}$ dates are summarized in Table 1 . Solid lines joining cores represent the position of the Holocene seismic boundaries (D500 to D620c) described in the text (based on seismic velocities measured on cores). The corresponding positions of seismic units (U500 to U620c) are also reported. Note that core RHS-KS22 (8.45m long, located on the modern Roustan deltaic lobe) did not reach D620c. 
Figure 8. Photos from selected cores illustrating the main sedimentary facies of the Rhone subaqueous delta. Facies 1, corresponding to tempestite deposits ((A) Core RHS-KS40: 615$635 \mathrm{~cm}$; (A'): RHS-KS22: 708-728 cm), is characterized by silt or rarely sand beds intercalated with fined-grained sediments. Few parallel or undulated laminations are emphasized by accumulation of dark minerals (image A). Facies 2, interpreted as a condensed interval ((B) RHS-KS40: 569-589 cm; (B') RHS-KS51: 505-525 cm), is composed of abundant shells and shell debris in a silty clay matrix. Few rounded pebbles can be observed (image B). Facies 3a1 ((C) RHS-KS54: 434-454 cm; (C') RHS-KS53: 730-750 cm) is made of structureless silty clay sediments with abundant bioturbation and biogenic contents. Facies $3 a 2$ ((D): RHS-KS56: 715-735 cm; (D’) RHS-KS55: 240-260 cm) is characterized by silty clay sediments with abundant hydrotroilite (organic matter traces) and bioturbation. Facies $\mathbf{3 b}$ ((E) RHS-KS53: 150-170 cm; (E’) RHS-KS27: $422-442 \mathrm{~cm}$ ) is characterized by silty clay sediments with numerous colour banding and rare silt laminae.

Figure 9. Synthetic chronology of the Holocene rapid climate changes recorded in the Rhone system (from source to sink). (A) Tripartite division of the Holocene Epoch (based on Walker et al., 2012). (B) The six Holocene Rapid Climate Changes (RCC) identified at the global scale and characterized by cooler conditions (and generally wetter conditions in Europe) (based on Wanner et al., 2011). (C) Hypothetical Holocene advance and retreat scenario of the Rhone Glacier (based on Goehring et al., 2011). Blue colour indicates periods of glacier advance whereas red colour indicates periods of glacier retreat. (D) Phases of enhanced hydrological activity (enhanced detrital input) recorded in Lake Bourget (France) (based on Debret et al., 2010; Arnaud et al., 2012). (E) Phases of increased sediment flux recorded in the Rhone delta plain (based on Bruneton et al., 2001; Arnaud-Fassetta, 2002; Provansal et al., 
2003). (F) Periods of increased storm activity recorded in the Pierre Blanche lagoon (central part of the Gulf of Lions) (based on Sabatier et al., 2012). (G) Seismic units and surface that characterize the Holocene Rhone subaqueous delta.

Table 1. Summary of the AMS ${ }^{14} \mathrm{C}$ dating samples used for this study, corrected for an assumed air-sea reservoir effect of 400 years.

Table 2. Synthesis of the main characteristics of the deglacial and Holocene seismic surfaces and units of the Rhone subaqueous delta.

Table 3. Principal characteristics and environmental interpretation of the five sedimentary facies identified in the Rhone subaqueous delta. 


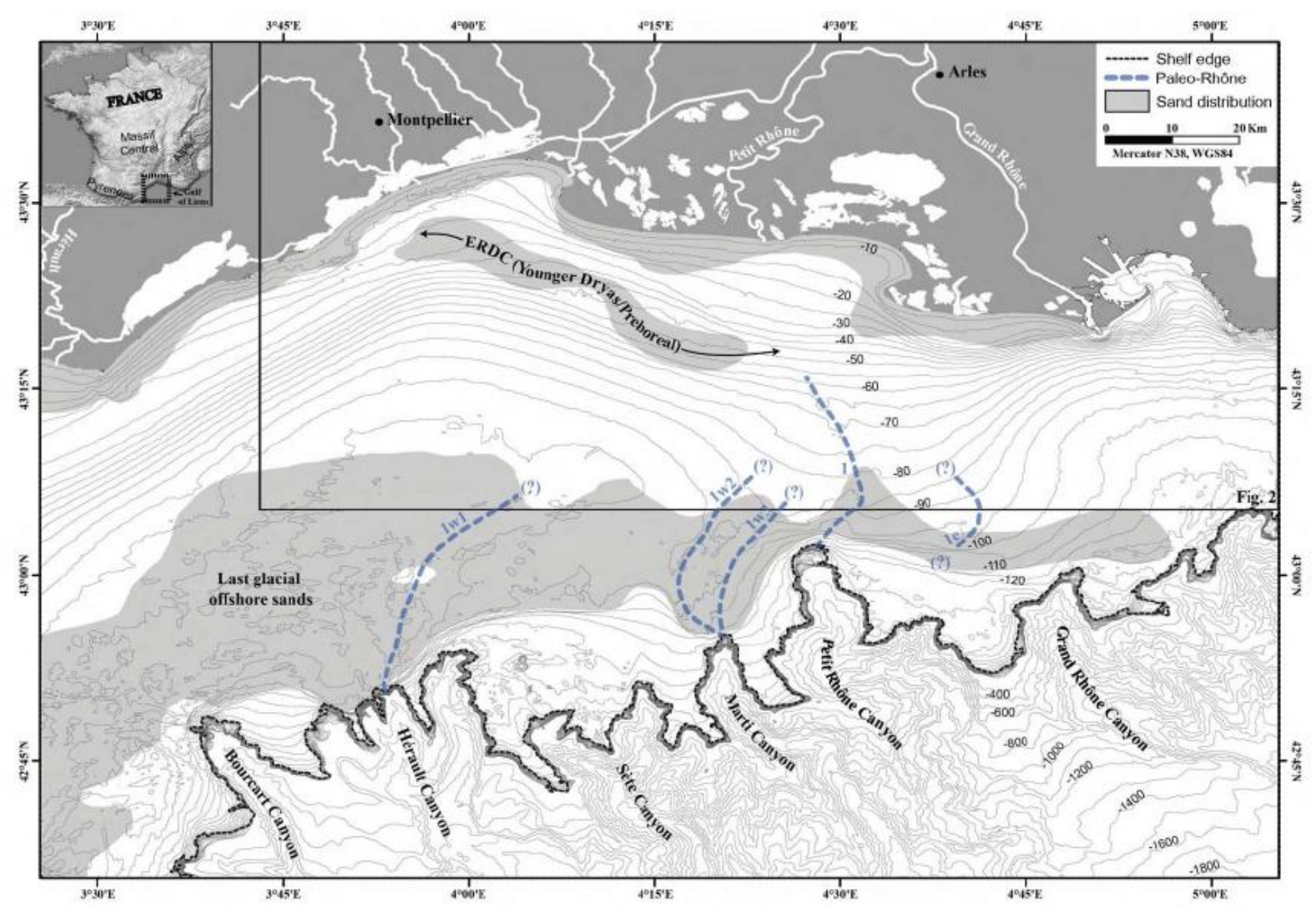

Figure 1 


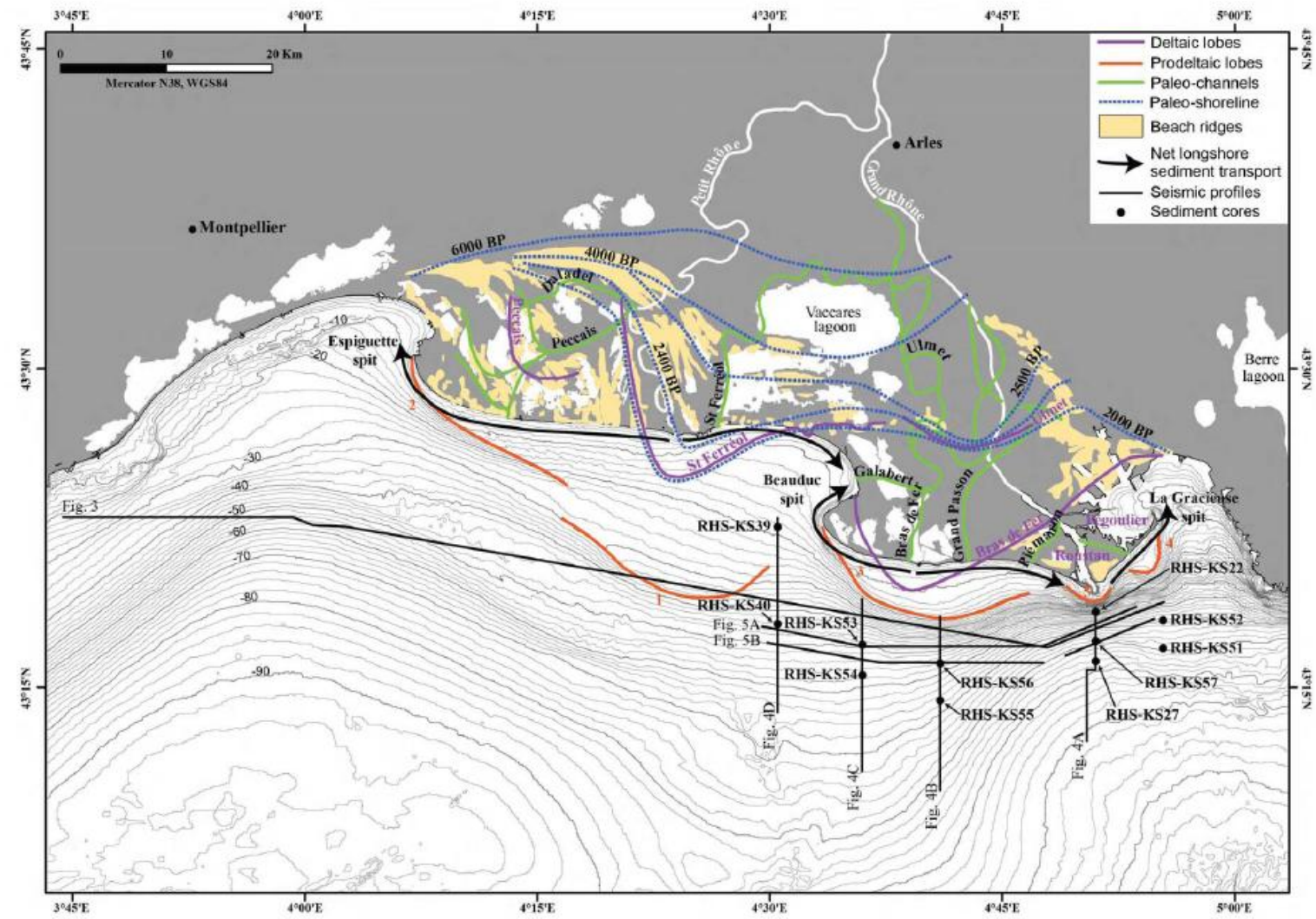

Figure 2 


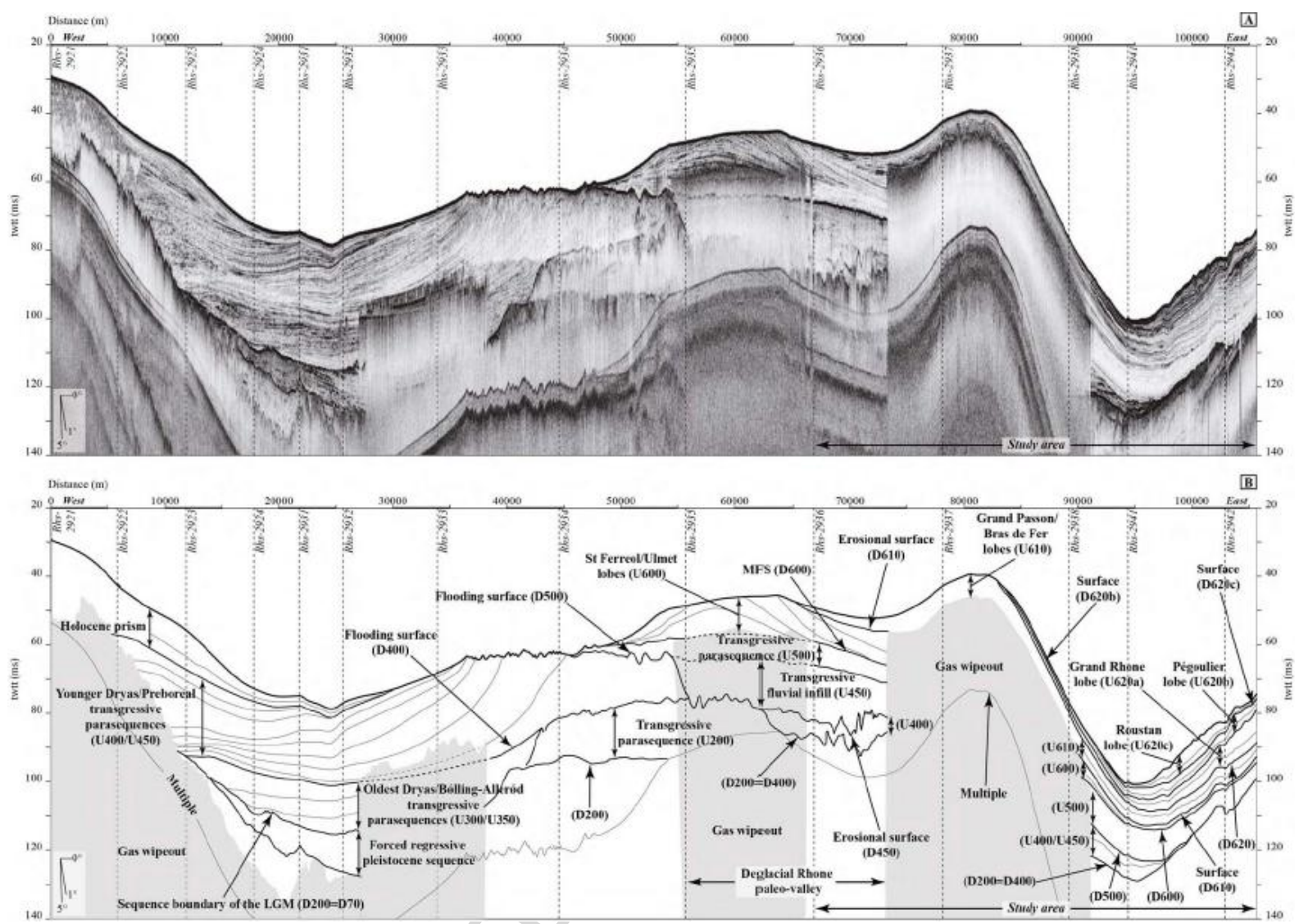

Figure 3 
A Dranes: (ail
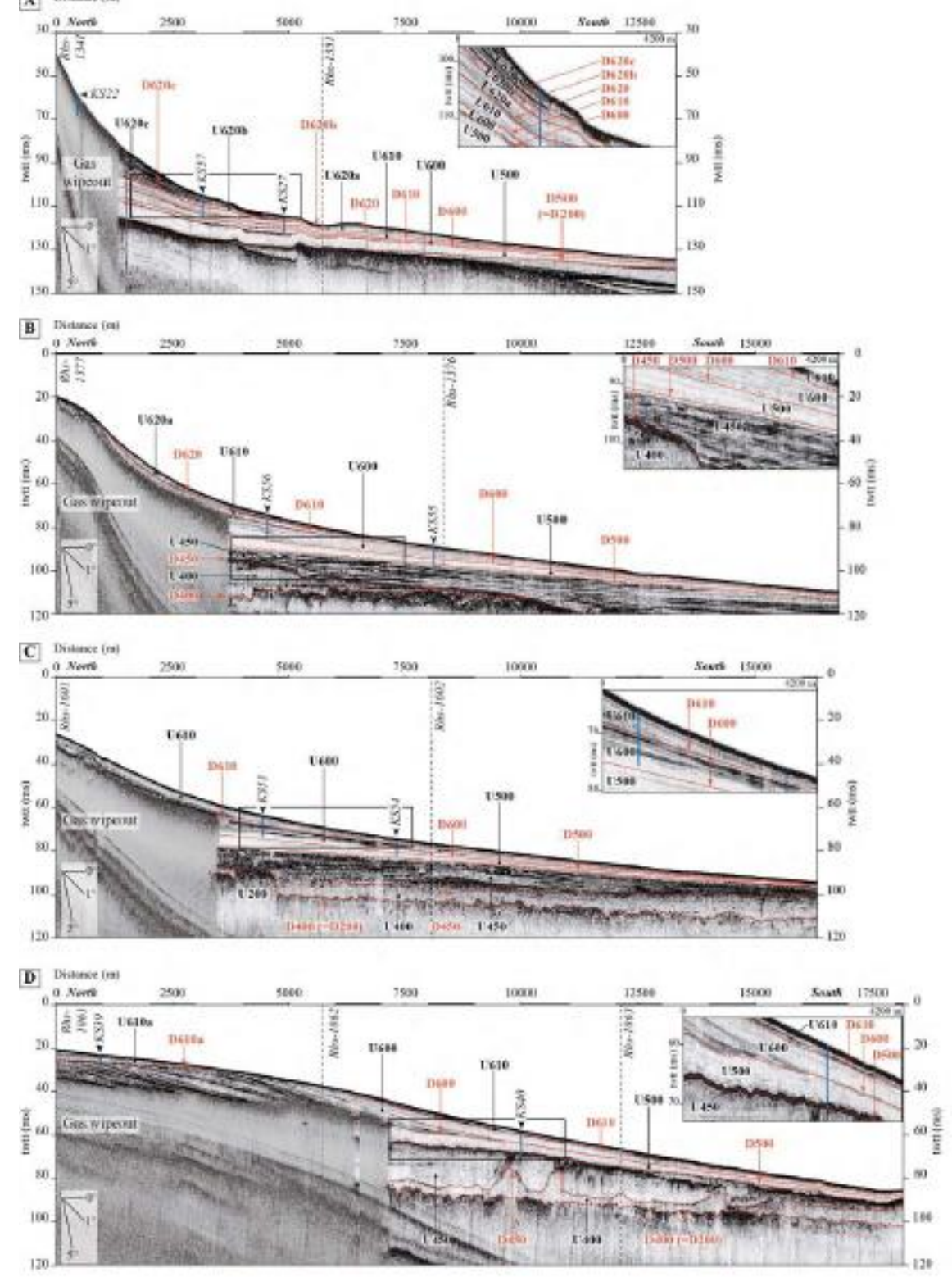

Figure 4 

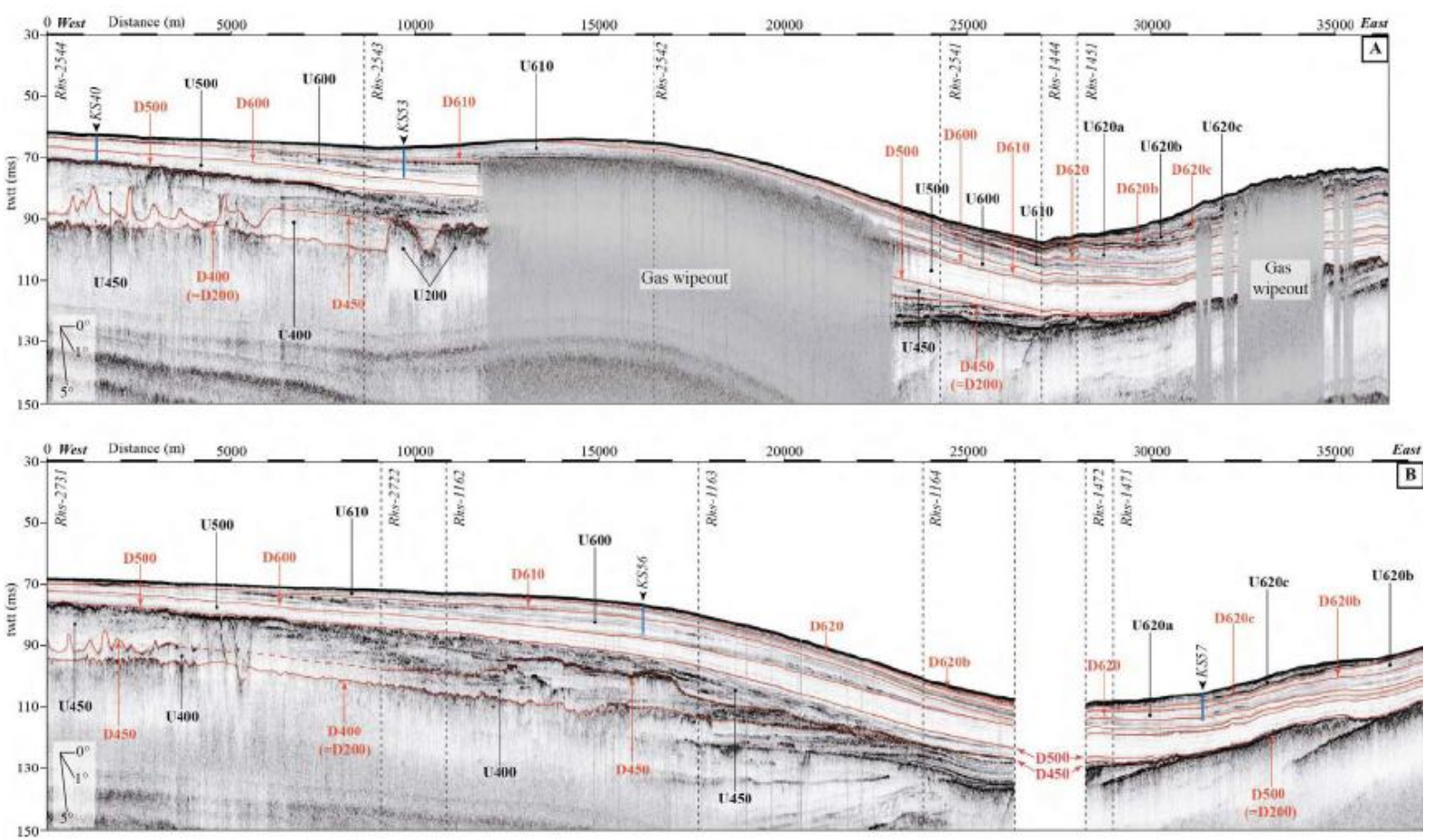

Figure 5 


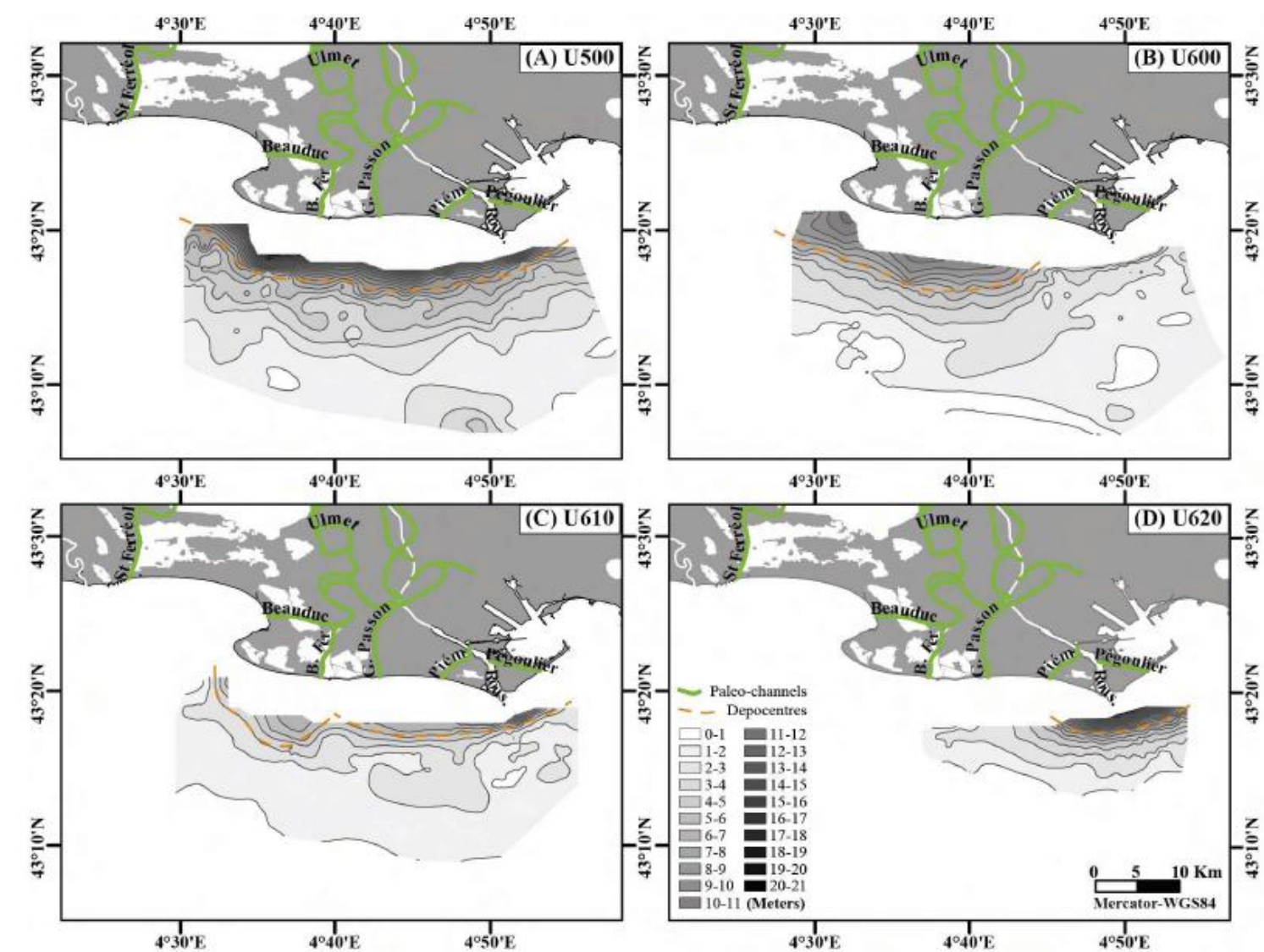

Figure 6 


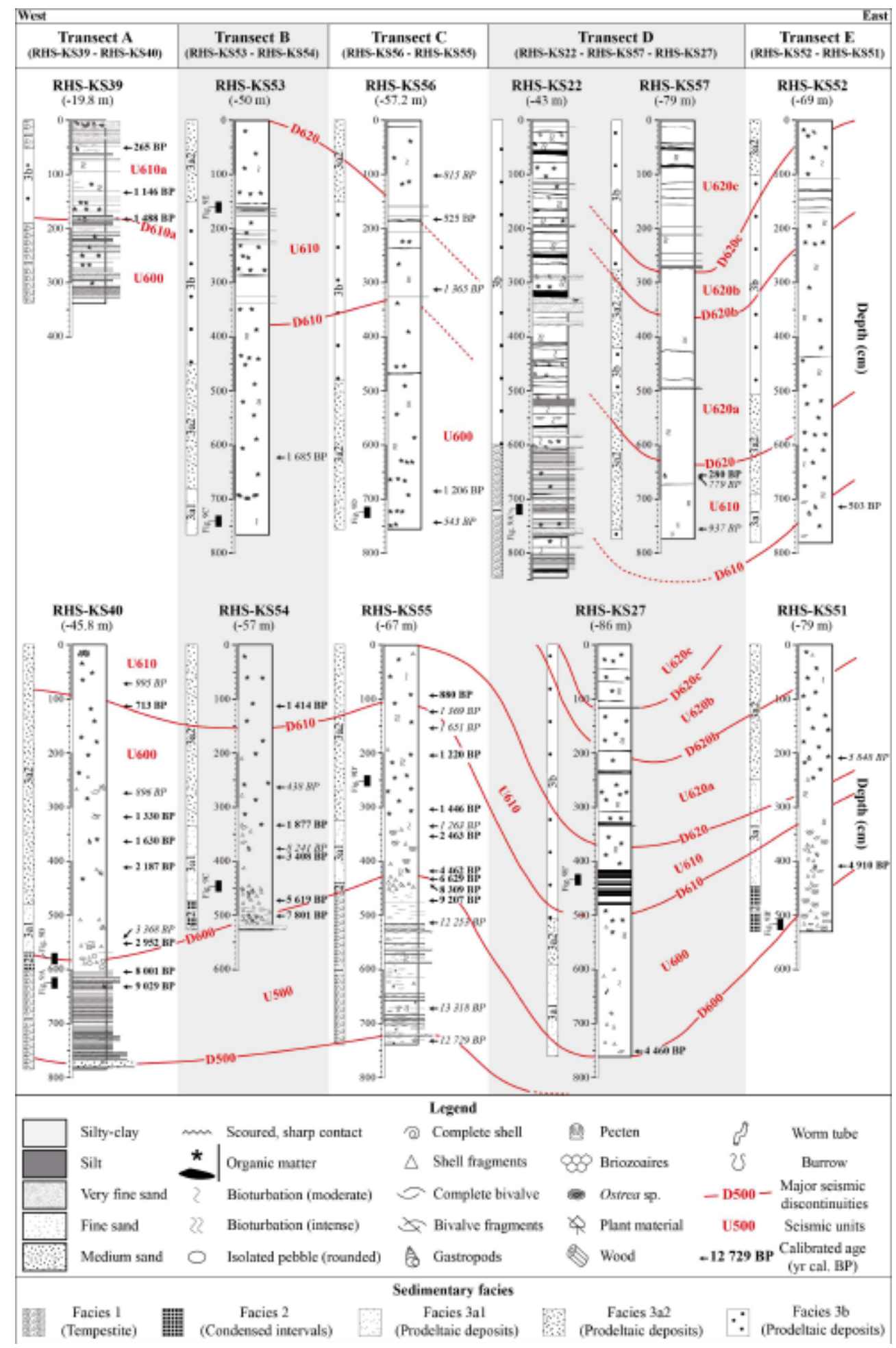

Figure 7 


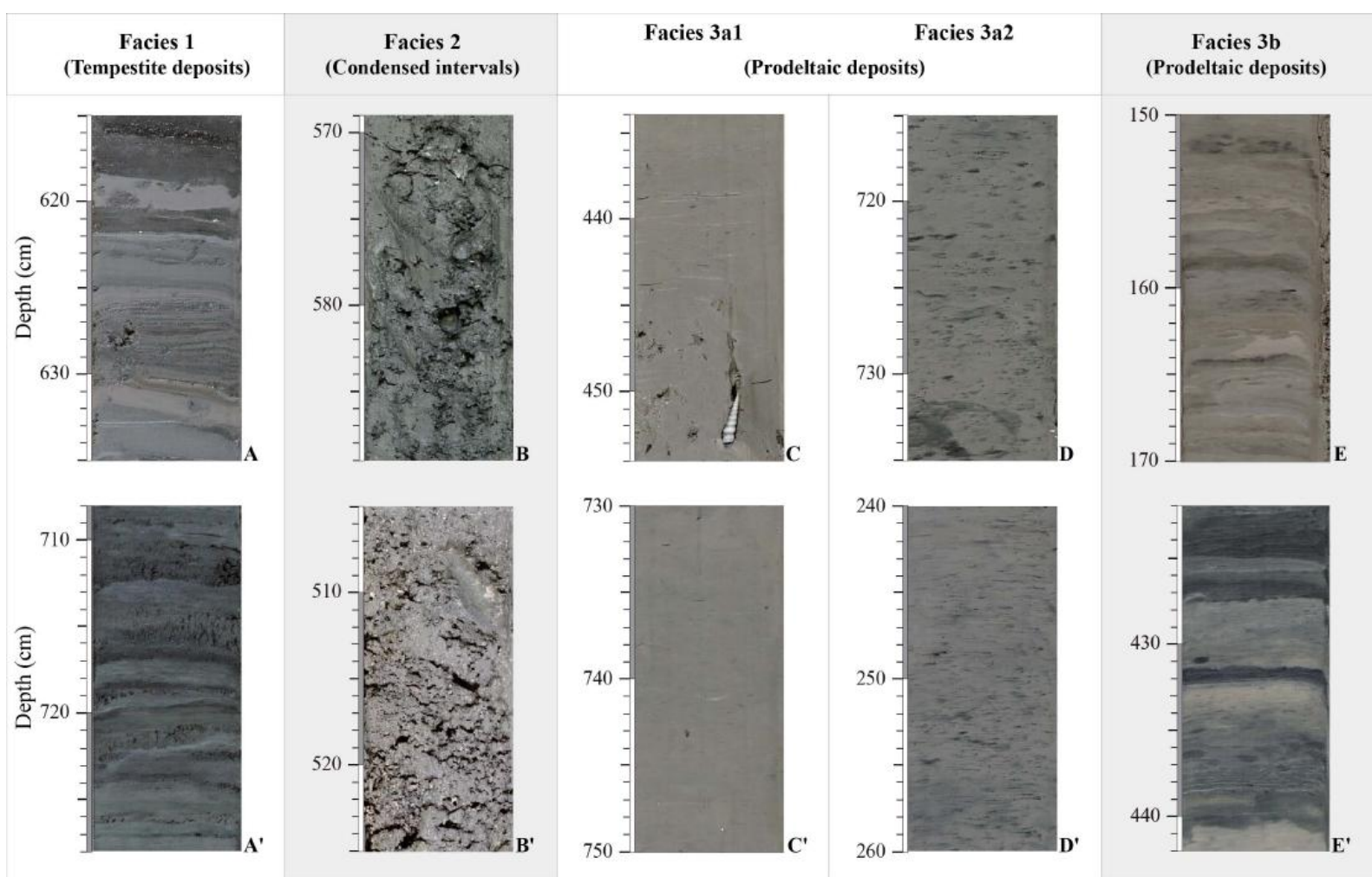

Figure 8 


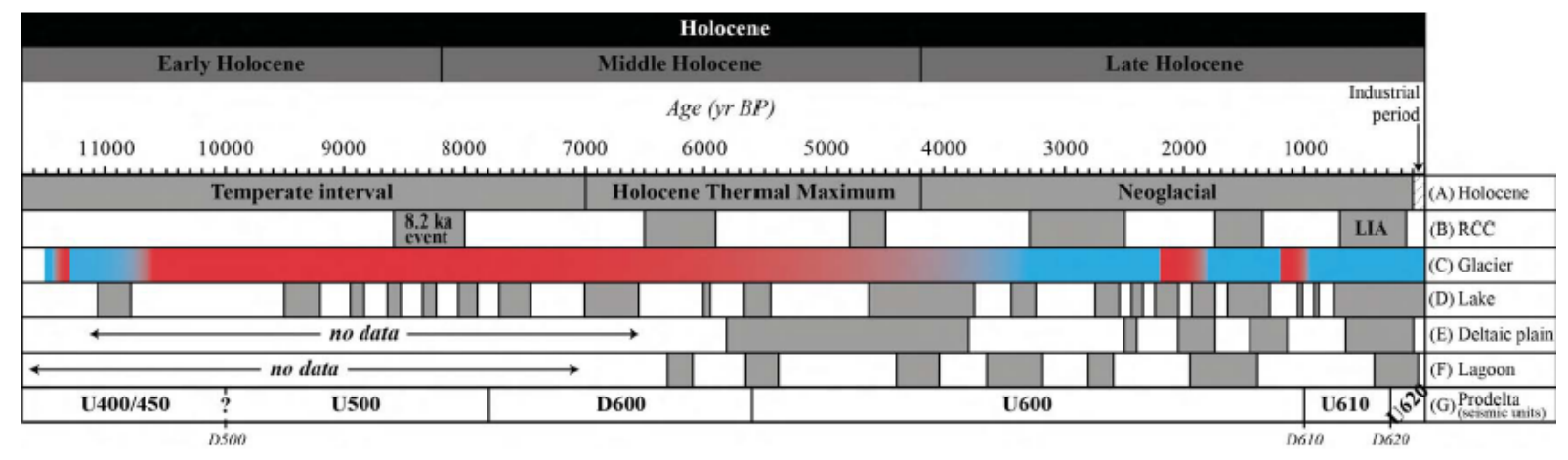

Figure 9 
Table 1

\begin{tabular}{|c|c|c|c|c|c|c|}
\hline $\begin{array}{l}\text { Depth } \\
(\mathbf{c m})\end{array}$ & Material & $\begin{array}{c}\text { Sample } \\
\text { weight } \\
\text { (mg) }\end{array}$ & $\begin{array}{l}\text { Core } \\
\text { and } \\
\text { lab } \\
\text { code }\end{array}$ & $\begin{array}{c}\text { Conventional } \\
{ }^{14} \mathrm{C} \text { age (yr } \\
\text { BP) }\end{array}$ & $\begin{array}{c}1 \text { Sigma } \\
\text { calibrated } \\
\text { age (yr cal. } \\
\text { BP) }\end{array}$ & $\begin{array}{l}\text { Probability } \\
\text { distribution }\end{array}$ \\
\hline \multicolumn{7}{|c|}{ RHS-KS39 } \\
\hline 48-52 & Turritella sp. & 924 & $\begin{array}{l}\text { SacA } \\
18956\end{array}$ & $610 \pm 30$ & $232-298$ & 1.000000 \\
\hline $\begin{array}{l}130- \\
132\end{array}$ & $\begin{array}{c}\text { Benthic } \\
\text { foraminifera }\end{array}$ & 11.4 & $\begin{array}{c}\text { SacA } \\
27194\end{array}$ & $1585 \pm 30$ & $\begin{array}{l}1097-1194 \\
1196-1200\end{array}$ & $\begin{array}{l}0.971087 \\
0.028913\end{array}$ \\
\hline $\begin{array}{l}180- \\
181\end{array}$ & Turritella sp. & 342 & $\begin{array}{c}\text { SacA } \\
18957\end{array}$ & $1945 \pm 35$ & $1434-1541$ & 1.000000 \\
\hline \multicolumn{7}{|c|}{ RHS-KS40 } \\
\hline 70-73 & $\begin{array}{c}\text { Benthic } \\
\text { foraminifera }\end{array}$ & 9.4 & $\begin{array}{c}\text { SacA } \\
23198\end{array}$ & $1450 \pm 30$ & $953-1036$ & 1.000000 \\
\hline $\begin{array}{l}110- \\
113\end{array}$ & $\begin{array}{c}\text { Benthic } \\
\text { foraminifera }+ \\
\text { Turritella } \mathrm{sp} .\end{array}$ & 15,7 & $\begin{array}{c}\text { SacA } \\
23199\end{array}$ & $1180 \pm 30$ & $679-747$ & 1.000000 \\
\hline $\begin{array}{l}273- \\
277\end{array}$ & Arca tetragona & 608 & $\begin{array}{c}\text { SacA } \\
18958\end{array}$ & $1350 \pm 35$ & $851-941$ & 1.000000 \\
\hline $\begin{array}{l}319- \\
320\end{array}$ & Pecten sp. & 55 & $\begin{array}{c}\text { SacA } \\
20576\end{array}$ & $1795 \pm 30$ & $1293-1366$ & 1.000000 \\
\hline $\begin{array}{l}363- \\
365\end{array}$ & Turritella sp. & 415 & $\begin{array}{l}\text { SacA } \\
18959\end{array}$ & $2060 \pm 40$ & $1573-1687$ & 1.000000 \\
\hline $\begin{array}{l}411- \\
413\end{array}$ & $\begin{array}{c}\text { Benthic } \\
\text { foraminifera + } \\
\text { Turritella } \mathrm{sp} .\end{array}$ & & $\begin{array}{l}\text { SacA } \\
23200\end{array}$ & $2510 \pm 30$ & $2128-2246$ & 1.000000 \\
\hline $\begin{array}{c}540- \\
542\end{array}$ & $\begin{array}{c}\text { Elphidium } \\
\text { crispum }\end{array}$ & & $\begin{array}{l}\text { SacA } \\
23201\end{array}$ & $3485 \pm 30$ & $3330-3406$ & 1.000000 \\
\hline $\begin{array}{c}551- \\
554\end{array}$ & $\begin{array}{c}\text { Acanthocardia } \\
\text { aculeata }\end{array}$ & 2739 & $\begin{array}{l}\text { SacA } \\
18960\end{array}$ & $3165 \pm 45$ & $2879-3025$ & 1.000000 \\
\hline $\begin{array}{c}603- \\
604\end{array}$ & $\begin{array}{c}\text { Elphidium } \\
\text { crispum }\end{array}$ & 11,4 & $\begin{array}{l}\text { SacA } \\
23202\end{array}$ & $7555 \pm 35$ & $7954-8048$ & 1.000000 \\
\hline 631 & $\begin{array}{l}\text { Buccinum } \\
\text { undatum }\end{array}$ & 236,7 & $\begin{array}{c}\text { SacA } \\
23203\end{array}$ & $8425 \pm 35$ & $8983-9075$ & 1.000000 \\
\hline \multicolumn{7}{|c|}{ RHS-KS53 } \\
\hline $\begin{array}{l}620- \\
623\end{array}$ & $\begin{array}{c}\text { Benthic } \\
\text { foraminifera }\end{array}$ & 10,3 & $\begin{array}{l}\text { SacA } \\
27195\end{array}$ & $2110 \pm 35$ & $1630-1739$ & 1.000000 \\
\hline \multicolumn{7}{|c|}{ RHS-KS54 } \\
\hline $\begin{array}{l}110- \\
113\end{array}$ & $\begin{array}{l}\text { Benthic and } \\
\text { Planktonic } \\
\text { foraminifera }\end{array}$ & 8,4 & $\begin{array}{l}\text { SacA } \\
27196\end{array}$ & $1870 \pm 30$ & $1364-1463$ & 1.000000 \\
\hline $\begin{array}{l}261- \\
262\end{array}$ & Turritella sp. & 43,7 & $\begin{array}{c}\text { SacA } \\
27197\end{array}$ & $785 \pm 35$ & $397-478$ & 1.000000 \\
\hline $330-$ & $\begin{array}{c}\text { Benthic } \\
\text { foraminifera }\end{array}$ & 11,9 & $\begin{array}{c}\text { SacA } \\
27198\end{array}$ & $2270 \pm 30$ & $1833-1920$ & 1.000000 \\
\hline $\begin{array}{l}377- \\
378\end{array}$ & Turritella sp. & 466 & $\begin{array}{l}\text { SacA } \\
20577\end{array}$ & $7770 \pm 45$ & $8187-8295$ & 1.000000 \\
\hline $\begin{array}{l}390- \\
392\end{array}$ & $\begin{array}{c}\text { Benthic } \\
\text { foraminifera }\end{array}$ & 11,4 & $\begin{array}{l}\text { SacA } \\
27199\end{array}$ & $3530 \pm 30$ & $3369-3447$ & 1.000000 \\
\hline
\end{tabular}




\begin{tabular}{|c|c|c|c|c|c|c|}
\hline $\begin{array}{l}470- \\
471\end{array}$ & $\begin{array}{c}\text { Benthic } \\
\text { foraminifera }\end{array}$ & 12,8 & $\begin{array}{l}\text { SacA } \\
27200\end{array}$ & $5270 \pm 35$ & $5582-5655$ & 1.000000 \\
\hline 513 & Turritella sp. & 89 & $\begin{array}{l}\text { SacA } \\
18970\end{array}$ & $7340 \pm 50$ & $7738-7865$ & 1.000000 \\
\hline \multicolumn{7}{|c|}{ RHS-KS56 } \\
\hline $\begin{array}{l}99- \\
102\end{array}$ & $\begin{array}{c}\text { Benthic } \\
\text { foraminifera + } \\
\text { Turritella sp. }\end{array}$ & 10,9 & $\begin{array}{l}\text { SacA } \\
23212\end{array}$ & $1265 \pm 30$ & & 1.000000 \\
\hline $\begin{array}{l}179- \\
182\end{array}$ & $\begin{array}{l}\text { Benthic and } \\
\text { Planktonic } \\
\text { foraminifera }\end{array}$ & 7,5 & $\begin{array}{l}\text { SacA } \\
23213\end{array}$ & & $9-551$ & 1.000000 \\
\hline $\begin{array}{l}309- \\
312\end{array}$ & $\begin{array}{l}\text { Benthic and } \\
\text { Planktonic } \\
\text { foraminifera }\end{array}$ & 8 & $\begin{array}{l}\text { SacA } \\
23214\end{array}$ & & $1323-1406$ & 1.000000 \\
\hline $\begin{array}{l}680- \\
684\end{array}$ & $\begin{array}{c}\text { Benthic } \\
\text { foraminifera }\end{array}$ & 12 & $\begin{array}{l}\text { SacA } \\
27206\end{array}$ & & $1168-1243$ & 1.000000 \\
\hline $\begin{array}{l}741- \\
742\end{array}$ & Turritella sp. & 62,7 & $\begin{array}{r}\text { SacA } \\
23215\end{array}$ & $960 \pm 30$ & $517-569$ & 1.000000 \\
\hline \multicolumn{7}{|c|}{ RHS-KS55 } \\
\hline $90-93$ & $\begin{array}{c}\text { Benthic } \\
\text { foraminifera }\end{array}$ & 9,5 & $\begin{array}{l}\text { SacA } \\
27201\end{array}$ & $1335 \pm 30$ & $839-921$ & 1.000000 \\
\hline $\begin{array}{l}120- \\
123\end{array}$ & $\begin{array}{c}\text { Benthic } \\
\text { foraminifera }\end{array}$ & & $\begin{array}{l}\text { SacA } \\
27202\end{array}$ & $1840 \pm 30$ & $1325-1412$ & 1.000000 \\
\hline $\begin{array}{l}150- \\
153\end{array}$ & $\begin{array}{c}\text { Benthic } \\
\text { foraminifera }\end{array}$ & & $\begin{array}{l}\text { SacA } \\
23204\end{array}$ & $2080 \pm 35$ & $1598-1704$ & 1.000000 \\
\hline $\begin{array}{l}200- \\
203\end{array}$ & $\begin{array}{c}\text { Benthic } \\
\text { foraminifera }\end{array}$ & Q & $\begin{array}{l}\text { SacA } \\
23205\end{array}$ & $1655 \pm 30$ & $1184-1256$ & 1.000000 \\
\hline $\begin{array}{l}300- \\
303\end{array}$ & $\begin{array}{c}\text { Benthic } \\
\text { foraminifera }+ \\
\text { Turritella } \mathrm{sp} .\end{array}$ & 10,9 & $\begin{array}{c}\text { SacA } \\
23206\end{array}$ & $1900 \pm 30$ & $1400-1492$ & 1.000000 \\
\hline $\begin{array}{c}335- \\
336\end{array}$ & $\begin{array}{c}\text { Benthic } \\
\text { foraminifera + } \\
\text { Turritella sp. }+ \\
\text { Bivalves }\end{array}$ & 10 & $\begin{array}{l}\text { SacA } \\
23207\end{array}$ & $1705 \pm 30$ & $1234-1292$ & 1.000000 \\
\hline $\begin{array}{l}350- \\
353\end{array}$ & $\begin{array}{c}\text { Benthic } \\
\text { foraminifera }\end{array}$ & 11,3 & $\begin{array}{c}\text { SacA } \\
27203\end{array}$ & $2760 \pm 35$ & $2376-2549$ & 1.000000 \\
\hline $\begin{array}{l}417- \\
420\end{array}$ & Turritella sp. & 896 & $\begin{array}{l}\text { Poz- } \\
35061\end{array}$ & $4335 \pm 35$ & $4415-4508$ & 1.000000 \\
\hline $\begin{array}{l}430- \\
433\end{array}$ & $\begin{array}{c}\text { Benthic } \\
\text { foraminifera }\end{array}$ & 10,5 & $\begin{array}{c}\text { SacA } \\
27204\end{array}$ & $6190 \pm 40$ & $6571-6687$ & 1.000000 \\
\hline $\begin{array}{l}440- \\
443\end{array}$ & Nucula sp. & 11,2 & $\begin{array}{l}\text { SacA } \\
27205\end{array}$ & $7830 \pm 40$ & $8259-8358$ & 1.000000 \\
\hline $\begin{array}{l}470- \\
473\end{array}$ & $\begin{array}{c}\text { Benthic } \\
\text { foraminifera }\end{array}$ & 10,2 & $\begin{array}{c}\text { SacA } \\
23208\end{array}$ & $8565 \pm 35$ & $9140-9273$ & 1.000000 \\
\hline $\begin{array}{l}510- \\
513\end{array}$ & $\begin{array}{l}\text { Elphidium } \\
\text { crispum }\end{array}$ & 10.1 & $\begin{array}{c}\text { SacA } \\
23209\end{array}$ & $10790 \pm 40$ & $\begin{array}{l}12175- \\
12331\end{array}$ & 1.000000 \\
\hline $\begin{array}{l}670- \\
673\end{array}$ & $\begin{array}{c}\text { Benthic } \\
\text { foraminifera }\end{array}$ & 13 & $\begin{array}{c}\text { SacA } \\
23210\end{array}$ & $11855 \pm 45$ & $\begin{array}{c}13263- \\
13373\end{array}$ & 1.000000 \\
\hline $\begin{array}{l}730- \\
733\end{array}$ & $\begin{array}{l}\text { Elphidium } \\
\text { crispum }\end{array}$ & 10.6 & $\begin{array}{r}\text { SacA } \\
23211\end{array}$ & $11280 \pm 40$ & $\begin{array}{l}12650- \\
12808\end{array}$ & 1.000000 \\
\hline
\end{tabular}




\begin{tabular}{|c|c|c|c|c|c|c|}
\hline \multicolumn{7}{|c|}{ RHS-KS57 } \\
\hline $\begin{array}{l}350- \\
353\end{array}$ & $\begin{array}{c}\text { Benthic } \\
\text { foraminifera }\end{array}$ & 9.7 & $\begin{array}{l}\text { SacA } \\
23216\end{array}$ & $810 \pm 30$ & $429-483$ & 1.000000 \\
\hline $\begin{array}{l}651- \\
654\end{array}$ & $\begin{array}{c}\text { Benthic } \\
\text { foraminifera }\end{array}$ & 10.9 & $\begin{array}{l}\text { SacA } \\
27207\end{array}$ & $1245 \pm 30$ & $731-827$ & 1.000000 \\
\hline 652 & Turritella sp. & 980 & $\begin{array}{l}\text { SacA } \\
15957\end{array}$ & $635 \pm 30$ & $253-306$ & 1.000000 \\
\hline $\begin{array}{l}750- \\
753\end{array}$ & $\begin{array}{c}\text { Benthic } \\
\text { foraminifera }\end{array}$ & 13 & $\begin{array}{l}\text { SacA } \\
23217\end{array}$ & $1395 \pm 30$ & $904-970$ & 1.000000 \\
\hline \multicolumn{7}{|c|}{ RHS-KS27 } \\
\hline $\begin{array}{l}750- \\
753\end{array}$ & $\begin{array}{c}\text { Acanthocardia } \\
\text { echinata }\end{array}$ & 4827 & $\begin{array}{l}\text { Poz- } \\
29500\end{array}$ & $4330 \pm 40$ & $4408-4511$ & 1.000000 \\
\hline \multicolumn{7}{|c|}{ RHS-KS52 } \\
\hline $\begin{array}{l}713- \\
714\end{array}$ & Turritella sp. & 266 & $\begin{array}{l}\text { SacA } \\
18969\end{array}$ & $890 \pm 35$ & $479-528$ & 1.000000 \\
\hline \multicolumn{7}{|c|}{ RHS-KS51 } \\
\hline 209 & Turritella sp. & 180 & $\begin{array}{l}\text { SacA } \\
18967\end{array}$ & $5475 \pm 45$ & $5788-5908$ & 1.000000 \\
\hline $\begin{array}{l}409- \\
410\end{array}$ & Pecten sp. & 903 & $\begin{array}{l}\text { Poz- } \\
35060\end{array}$ & $4700 \pm 40$ & $4853-4968$ & 1.000000 \\
\hline
\end{tabular}


Table 2

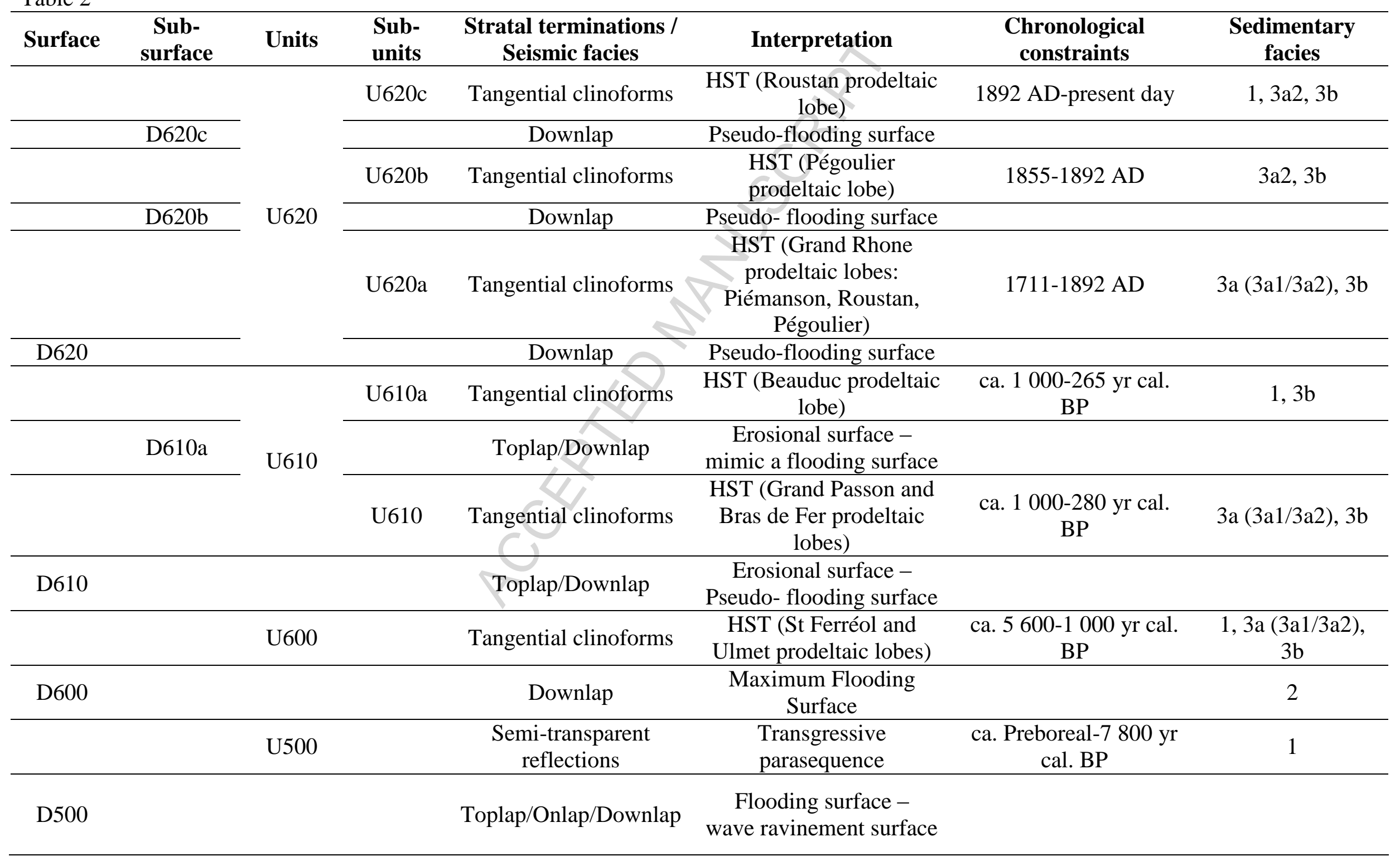




\begin{tabular}{ccccc}
\hline U450 & $\begin{array}{c}\text { Sub-horizontal } \\
\text { reflections }\end{array}$ & $\begin{array}{c}\text { Transgressive } \\
\text { parasequence }\end{array}$ & $\begin{array}{c}\text { Post 10 500 yr cal. BP } \\
\text { (Preboreal) }\end{array}$ & Not available \\
\hline D450 & Toplap/Onlap & Erosional surface & \\
\hline D400 & $\begin{array}{c}\text { Clinoforms to sub- } \\
\text { horizontal reflections }\end{array}$ & $\begin{array}{c}\text { Transgressive } \\
\text { Parasequence - Early } \\
\text { Rhone Deltaic Complex }\end{array}$ & $\begin{array}{c}\text { Younger } \\
\text { Dryas/Preboreal }\end{array}$ \\
\hline N200 & Downlap & Flooding surface & \\
\hline D200 & $\begin{array}{c}\text { Chaotic to very } \\
\text { discontinuous } \\
\text { reflections }\end{array}$ & $\begin{array}{c}\text { Earliest transgressive } \\
\text { parasequence }\end{array}$ & ? (no core available) \\
\hline
\end{tabular}




\begin{tabular}{|c|c|c|}
\hline \multirow{2}{*}{$\begin{array}{c}\text { Core } \\
\text { (depth in } \mathbf{c m}) \\
\end{array}$} & \multicolumn{2}{|c|}{ Sedimentary Facies } \\
\hline & Feature & Environment \\
\hline & \multicolumn{2}{|c|}{ Facies 1} \\
\hline $\begin{array}{l}\text { RHS-KS40 (784-600) } \\
\text { RHS-KS54 (526-520) } \\
\text { RHS-KS55 (738-460) } \\
\text { RHS-KS39 (338-190) } \\
\text { RHS-KS22 (845-600) }\end{array}$ & $\begin{array}{l}\text { Silt or sand beds with rare } \\
\text { parallel or undulated } \\
\text { laminations intercalated in } \\
\text { fine-grained sediments }\end{array}$ & $\begin{array}{l}\text { Near-shore storm-influenced } \\
\text { environment }\end{array}$ \\
\hline & \multicolumn{2}{|c|}{ Facies 2} \\
\hline $\begin{array}{l}\text { RHS-KS40 (600-570) } \\
\text { RHS-KS54 (520-470) } \\
\text { RHS-KS55 (460-440) } \\
\text { RHS-KS51 (530-450) }\end{array}$ & $\begin{array}{c}\text { Silty clay matrix with } \\
\text { heterolithic contents } \\
\text { (Turritella } \text { sp., bivalves, } \\
\text { and in few cases rounded } \\
\text { pebbles) }\end{array}$ & $\begin{array}{l}\text { Condensed interval of the } \\
\text { maximum flooding surface }\end{array}$ \\
\hline & \multicolumn{2}{|c|}{\begin{tabular}{rr|} 
& Facies 3a1 \\
\end{tabular}} \\
\hline $\begin{array}{l}\text { RHS-KS40 (570-480) } \\
\text { RHS-KS54 (470-330) } \\
\text { RHS-KS55 (440-320) } \\
\text { RHS-KS27 (760-590) } \\
\text { RHS-KS51 (450-250) } \\
\text { RHS-KS53 (765-680) } \\
\text { RHS-KS52 (780-690) }\end{array}$ & $\begin{array}{l}\text { Structureless silty clay } \\
\text { sediments with biogenic } \\
\text { contents (bryozoan debris, } \\
\text { shell fragments, Turritella } \\
\text { sp. and bivalves) and } \\
\text { abundant bioturbation }\end{array}$ & $\begin{array}{c}\text { Prodeltaic environment } \\
\text { (shallow water setting with } \\
\text { occasional fluvial influence) }\end{array}$ \\
\hline & Fac & es $3 \mathbf{a} 2$ \\
\hline $\begin{array}{c}\text { RHS-KS40 (480-0) } \\
\text { RHS-KS54 (330-0) } \\
\text { RHS-KS55 (320-0) } \\
\text { RHS-KS27 (590-510) } \\
\text { RHS-KS51 }(250-0) \\
\text { RHS-KS53 }(680-450 ; 150-0) \\
\text { RHS-KS56 (755-480;150-0) } \\
\text { RHS-KS57 (760-500;420-280) } \\
\text { RHS-KS52 (690-510;100-0) } \\
\end{array}$ & $\begin{array}{l}\text { Structureless silty clay } \\
\text { sediments with abundant } \\
\text { hydrotroilites and } \\
\text { bioturbation }\end{array}$ & $\begin{array}{c}\text { Prodeltaic environment } \\
\text { (shallow water setting with } \\
\text { occasional fluvial influence) }\end{array}$ \\
\hline 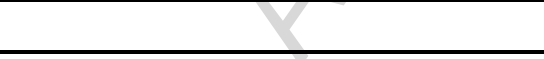 & \multicolumn{2}{|c|}{ Facies 3b } \\
\hline $\begin{array}{c}\text { RHS-KS27 (510-0) } \\
\text { RHS-KS53 (450-150) } \\
\text { RHS-KS56 (480-150) } \\
\text { RHS-KS57 (771-760; } \\
\text { 500-420;280-0) } \\
\text { RHS-KS52 (510-100) } \\
\text { RHS-KS39 (190-0) } \\
\text { RHS-KS22 (600-0) }\end{array}$ & $\begin{array}{l}\text { Silty clay sediments with } \\
\text { abundant colour banding, } \\
\text { few silt laminae, and } \\
\text { moderate bioturbation }\end{array}$ & $\begin{array}{c}\text { Prodeltaic environment } \\
\text { (shallow water setting with } \\
\text { occasional fluvial influence) }\end{array}$ \\
\hline
\end{tabular}

